OPEN ACCESS

Edited by:

Timothy Bowles,

University of California, Berkeley,

United States

Reviewed by:

Liming Ye,

Ghent University, Belgium Meredith T. Niles,

University of Vermont, United States

${ }^{*}$ Correspondence: Anne Elise Stratton aestrat@umich.edu

Specialty section:

This article was submitted to Agroecology and Ecosystem Services, a section of the journal

Frontiers in Sustainable Food Systems

Received: 18 March 2020

Accepted: 31 August 2020

Published: 22 October 2020

Citation:

Stratton AE, Kuhl L and Blesh J (2020) Ecological and Nutritional Functions of Agroecosystems as Indicators of Smallholder Resilience.

Front. Sustain. Food Syst. 4:543914. doi: 10.3389/fsufs.2020.543914

\section{Ecological and Nutritional Functions of Agroecosystems as Indicators of Smallholder Resilience}

\author{
Anne Elise Stratton ${ }^{1 *}$, Laura Kuhl ${ }^{2}$ and Jennifer Blesh ${ }^{1}$ \\ ${ }^{1}$ School for Environment and Sustainability, University of Michigan, Ann Arbor, MI, United States, ${ }^{2}$ School of Public Policy \\ and Urban Affairs and International Affairs Program, Northeastern University, Boston, MA, United States
}

Smallholder agriculture is the foundation of global food systems, yet smallholders face severe socio-economic and environmental challenges that can destabilize livelihoods and threaten their resilience. Given that smallholder farmers rely on household production to meet their nutritional needs, management of soil fertility, biodiversity, and other ecological characteristics of agroecosystems directly affects smallholders' capacity to produce sufficient crop nutrients for their diets. However, we lack explicit frameworks linking ecological and nutritional functions of agroecosystems, as well as research exploring farmers' adaptive capacity and agency in mediating these functions, and ultimately, agroecosystem resilience. To address these gaps, we developed an indicator framework to evaluate the complementary roles of ecological and nutritional functions of agroecosystems for smallholder resilience. Paired ecological and nutritional indicators were aggregated into an index representing four agroecosystem functions: (1) Productivity, (2) Diversity, (3) Quality, and (4) Functional Diversity. We then applied this framework and index to a case study of Q'eqchi' Maya smallholders in eastern Guatemala, using farm management and crop quality data from 60 households to determine the status of agroecosystem functions and assess coping and adaptive capacities in response to shocks. More than three-quarters of farms in the sample relied solely on household production of staples to meet their nutritional demands. Across farms, ecological and nutritional indicators were significantly related (Kendall's tau $=0.58, z=5.7, p<0.0001$ ), and we found both synergistic (Quality, Functional Diversity) and tradeoff (Productivity) relationships between indicator pairs. We found that farmers using ecological adaptation strategies such as cover cropping and agroforestry had significantly higher levels of agroecosystem functioning and resilience than farmers who were coping with shocks by working off-farm or renting land from plantations. Our findings demonstrate the importance of linking ecological and nutritional functions of agroecosystems through diversified management practices to leverage their synergies. Because smallholder agroecosystems underlie a third of the food system, understanding and promoting their resilience is critical for the social, ecological, and nutritional well-being of global populations.

Keywords: adaptive capacity, agroecology, functional diversity, synergies and tradeoffs, crop nutritional quality, indicator framework, food security and nutrition, land grab 


\section{INTRODUCTION}

Smallholder agriculture persists as the foundation of global food systems. Farms smaller than 2 hectares produce more than $30 \%$ of the world's food and occupy $24 \%$ of agricultural land (Herrero et al., 2017; Ricciardi et al., 2018), yet smallholders face severe socioeconomic and environmental challenges that can destabilize livelihoods and threaten their resilience (Scherr, 2000; Blesh and Wittman, 2015; Cohn et al., 2017). In degraded landscapes, where poor soil fertility can jeopardize crop yields, many smallholders are forced to compromise long-term sustainability to meet short-term production needs (Rodriguez et al., 2006; Power, 2010). While food production in the short-term is essential to maintain household nutrition, neglect for long-term ecological sustainability can make land unviable for future production. Thus, there is an interplay between ecological and nutritional functions of agroecosystems that may influence whether smallholders are able to adapt and continue farming within a deteriorating environmental context. Farmer management decisions can either increase or decrease these functions, demonstrating their capacity to adapt, and make incremental adjustments or changes that ultimately affect their resilience. Because smallholder agroecosystems support a third of the food system, understanding and promoting their adaptive capacity and resilience is critical for the social, ecological, and nutritional well-being of rural communities, and, ultimately, the global population.

Several recent studies operationalize agroecosystem resilience by developing indicators and metrics (Büchs, 2003; Cabell and Oelofse, 2012; Urruty et al., 2016; Jacobi et al., 2018). However, such frameworks neglect the ecological and nutritional interactions that contribute to agroecosystem functioning and resilience. Management of soil fertility, biodiversity, and other ecological characteristics on farms can directly affect the capacity of agroecosystems to produce sufficient crop nutrients for smallholder households to meet their nutritional demands (DeClerck et al., 2011; Allen et al., 2014). Smallholders depend largely on their own food production and local market availability for food security and nutrition (Jones, 2017), which tightens relationships between ecological and nutritional functions of local food production. To our knowledge, no prior study has developed an explicit framework to link ecological and nutritional functions of agroecosystems, or explored how, by employing strategies that enhance both ecological and nutritional functions, farmers' adaptive capacity and agency can mediate these agroecosystem functions, and resilience.

Our study developed an indicator framework to evaluate the complementary roles of ecological and nutritional functions of agroecosystems for smallholder resilience (Figure 1). We generated pairs of ecological and nutritional indicators of agroecosystem functions based on prior theoretical and empirical work and applied our framework to a case study of Q'eqchi' Maya smallholders in eastern Guatemala. The case study showcases the linkages between smallholder management decisions, adaptive capacity, and underlying ecological and nutritional functions that shape environmental and human health outcomes. While tradeoffs exist between practices that optimize either ecological or nutritional functions of agroecosystems, management strategies can also lead to synergies between them (Power, 2010), demonstrating the potential for smallholders to adapt and enhance resilience in a changing environment.

\section{BACKGROUND}

\section{Social-Ecological Resilience of Agroecosystems}

Social-ecological resilience offers a useful analytical framework to evaluate the long-term productive capacity of smallholder farms vulnerable to environmental and economic shocks (Folke, 2006; Cabell and Oelofse, 2012). Researchers frequently define social-ecological resilience as a system's capacity to respond to disturbance and shocks and retain its essential components and functions, as well as its capacity for learning and adaptation (Holling, 1973; Adger, 2000; Carpenter et al., 2001). Resilience was popularized in the ecological sciences but has since expanded into the social sciences. The concept has been adapted for social-ecological systems in order to account for differences in ecosystem function and feedbacks resulting from human agency (Berkes and Ross, 2013; Béné et al., 2016).

Agroecosystems represent coupled social-ecological systems that are characterized by complex interactions and feedbacks between components, including ecosystem services and rural livelihoods (Adger, 2000; Liu et al., 2007; Bailey and Buck, 2016). Social-ecological resilience, then, provides an increasingly common framework for linking social and ecological dimensions of food systems (Callo-Concha and Ewert, 2014; Jacobi et al., 2018), and by extension, the concept is useful for linking nutritional and ecological functions of agroecosystems.

Resilience in agroecosystems is achieved through the capacities of actors in the system. Thus, the concepts of coping, adaptive, and transformative capacities are tied to resilience. While all of these capacities offer avenues toward system resilience, they function through different mechanisms and result in distinct outcomes (Béné et al., 2012). For example, coping capacities are normally employed when shocks are minor and the objective is to maintain system stability (i.e., persistence), whereas adaptive capacities are useful when incremental adjustments to the system are necessary to increase flexibility in the face of shocks. When shocks or stresses exceed levels for which coping and adaptive capacities are sufficient, transformative capacities can come into play to shift the nature of the system entirely.

\section{Ecological Functions of Agroecosystems}

Basic ecosystem processes, including fluxes of energy and nutrients and interactions among species, drive different ecosystem functions. Some examples of functions that are central to nutrient cycling in agroecosystems include primary production, decomposition, and biological nitrogen fixation by legume species. In a positive state, each of these functions enables agroecosystems to maintain soil fertility and productivity over time. When negative, loss of agroecosystem functioning occurs. Ecological processes happen in part due to abiotic and biotic conditions outside of farmers' control, but farmers are able 


\section{FOOD SYSTEM}

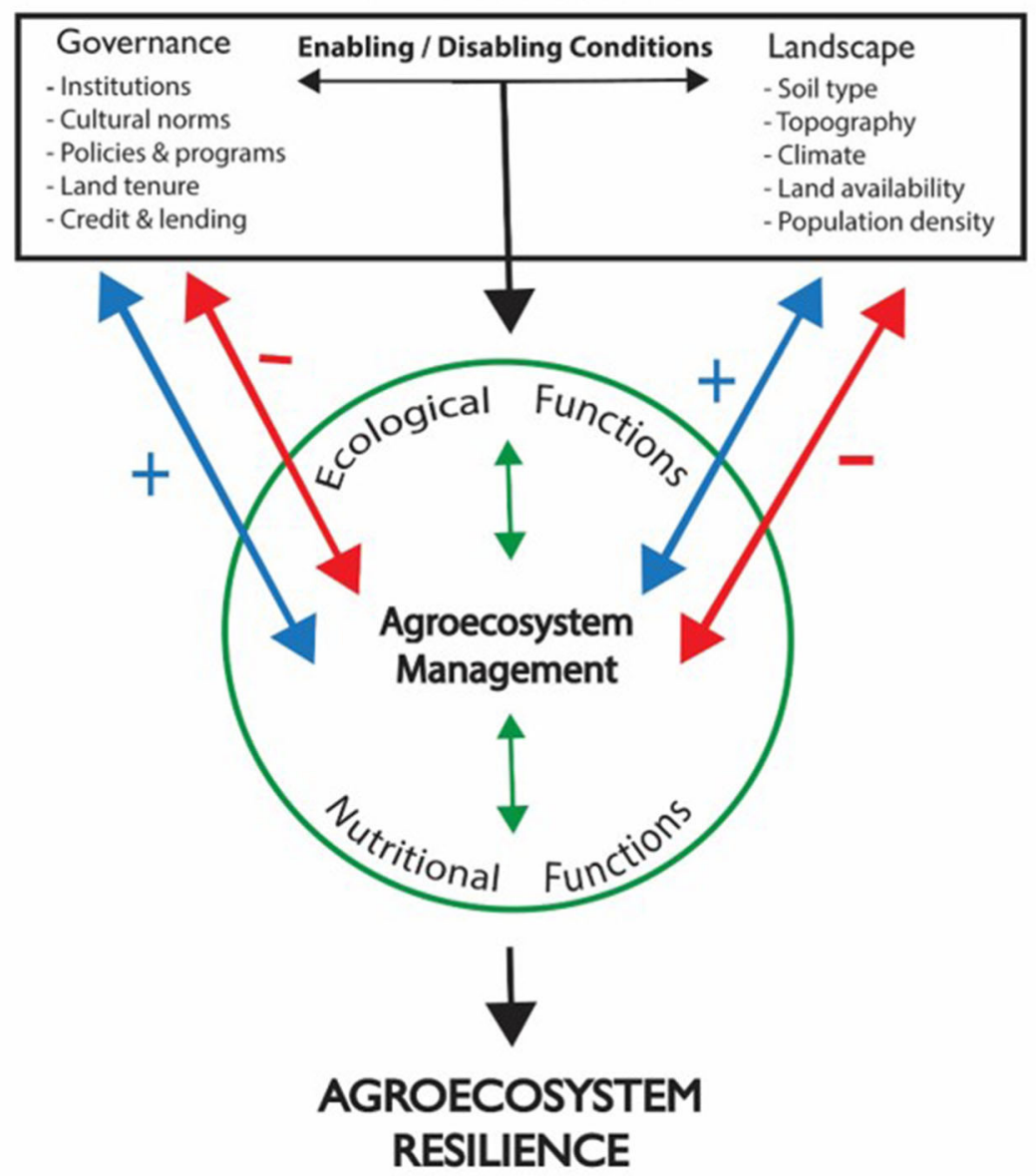

FIGURE 1 | Conceptual diagram of interactions between agroecosystem functioning and resilience. Farm management affects ecological and nutritional functions, which in turn drive changes in agroecosystem resilience. Green arrows inside the circle represent the interactions between ecological and nutritional functions, which are mediated by agroecosystem management practices and the adaptive capacity of farmers. Farm-level management decisions are embedded within food systems and associated governance and landscape conditions, which can trigger positive (+) or negative (-) feedbacks in agroecosystems.

to alter many agroecosystem functions through management practices (intentionally or unintentionally) (Drinkwater et al., 2008). Past work suggests that intentional management of ecological processes, or "agroecological management" (Kremen and Miles, 2012), results in resilience of desirable, or productive, states in agricultural systems (Peterson et al., 2018). Farm management strategies can therefore promote agroecosystem functioning and resilience (Bailey and Buck, 2016).

Agroecological management practices, in particular, can improve crop nutrient uptake in ecologically degraded systems by augmenting biotic interactions to enhance nutrient cycling (Brooker et al., 2016). For example, increasing the diversity of crop rotations with cover crops is a practice that can improve multiple ecosystem functions, or "multifunctionality" (Snapp et al., 2005; Finney and Kaye, 2016; Blesh, 2018). Among other functions, cover crops in the legume family supply nitrogen $(\mathrm{N})$ and carbon (C) to soils through biological $\mathrm{N}$ fixation and photosynthesis. These $\mathrm{N}$ and $\mathrm{C}$ inputs add to pools of bioavailable soil nutrients, as cover crops are generally not harvested but instead are incorporated into the soil at the end of the season as "green manures." This agroecological practice has therefore been shown to increase internal nutrient cycling and nutrient availability to primary crops, with potential to increase productivity over time (Wander et al., 1994; Blesh, 2019). More broadly, the addition of legume cover crops to crop rotations introduces additional plant traits that influence ecosystem functions, contributing to both agricultural biodiversity (agrobiodiversity) and crop functional diversity (Wood et al., 2015).

\section{Nutritional Functions of Agroecosystems}

As an extension of ecosystem functioning, DeClerck et al. (2011) proposed that, given agroecosystems' primary goal of food production for human nutrition and health, nutritional functions of agroecosystems should be measured alongside their ecological counterparts. Although their study proposed one indicator of 
nutritional function-nutritional functional diversity-a broad suite of nutritional functions has rarely been considered in assessments of agroecosystem performance and resilience, nor have nutritional functions been explicitly related to underlying ecological functions.

Other nutritional functions of agroecosystems include the quantity, diversity and nutritional quality of crops produced, as well as maintenance of genetic resources to improve traits of individual crops and diet diversity (Remans et al., 2011; Allen et al., 2014). Importantly, these indicators of nutritional function consider more than just yield or productivity, which has been the dominant metric for assessing agroecosystem performance since the Green Revolution (Cassidy et al., 2013). Favoring productivity as the sole goal of agroecosystems can falsely place household food security and rural livelihoods at odds with critical ecological and nutritional functions (Zhang et al., 2007; Bennett et al., 2009; Nelson et al., 2009).

Just as farm management practices impact ecological functioning, they also affect nutritional functions, including nutritional quality of crops and potential for increased dietary diversity, as well as productivity. Ecological functions therefore affect the overall ability of an agroecosystem to provide nutritional functions to people-through the production of a diverse selection of nutritious foods. Extending beyond the agroecosystem level, recent high-profile reports have highlighted transitioning to agroecological management as an innovative approach to enhance food security and nutrition globally [McIntyre et al., 2009; The High Level Panel of Experts (HLPE) on Food Security Nutrition, 2019].

Agroecological management frequently entails ecological and nutritional diversification of cropping systems. Diversified farms have high levels of interaction between plant species, and between plants and microorganisms, which can maximize the efficiency of nutrient use on farms (e.g., Matson et al., 1997; Shennan, 2008; Kremen and Miles, 2012). When nutrient use efficiency (defined as total nutrient harvested/total nutrient input) of crops increases, there is greater uptake of nutrients by crop species, which can increase crop nutritional quality. Greater nutrient use efficiency also tends to correspond with reduced nutrient losses through runoff, leaching, or other pathways (Robertson and Vitousek, 2009). Such management practices thus have direct impacts on environmental sustainability as well as the quantity and quality of food produced and consumed (i.e., nutritional yield) in an agroecosystem. At the same time, it is important to acknowledge potential tradeoffs between management strategies that maximize ecological or nutritional functions (e.g., Power, 2010; Kremen and Miles, 2012), often by favoring short-term nutritional functions (e.g., crop yield or income from crop sales in a single season) over longer-term ecological ones (e.g., soil organic matter formation, C storage, and nutrient retention) (e.g., Steffan-Dewenter et al., 2007).

Continuing the example of farm diversification with cover crops, we can identify specific links between the ecological and nutritional functions derived from this practice. Nutritional functions include supporting crop yields with nutrient inputs from legume $\mathrm{N}$ fixation (Blesh, 2018), and increasing availability of other nutrients that can make crops more nutrient-rich, particularly soil phosphorus from solubilization by acidic and enzymatic root exudates (Hinsinger et al., 2011; Xue et al., 2016). Reduced soil erosion is also likely to improve crop yields and nutrient availability, especially if the system in question is a lowinput smallholder farm on steep terrain (Vanek and Drinkwater, 2013). Increased yields in a resource-poor agricultural context could correspond to improved household food security or selfsufficiency, or to increased incomes, if crops are sold (Sibhatu et al., 2015b). Shifts in both ecological and nutritional functions of agroecosystems in this example illustrate the interactions resulting from farmer management decisions that can lead to agroecosystem resilience.

\section{INDICATOR FRAMEWORK \\ Prior Frameworks for Agroecosystem Functioning and Resilience}

Scholars have proposed frameworks for evaluating and enhancing food system resilience and sustainability (Tendall et al., 2015; Prosperi et al., 2016; Béné et al., 2019), rural landscape (Bailey and Buck, 2016) and livelihood resilience (Pelletier et al., 2016), working lands conservation and resilience (Kremen and Merenlender, 2018), and agricultural or agroecosystem resilience (van der Werf and Petit, 2002; Büchs, 2003; Cabell and Oelofse, 2012; Altieri et al., 2015; Blesh and Wittman, 2015; Prosperi et al., 2016), which include both environmental and food security indicators. These indicators have primarily considered the broader food system, including addressing questions of food supply, prices, and accessibility that drive food consumption, but have focused less on how these relationships play out in individual agroecosystems, and how management decisions at the farm level affect these broader food system dynamics.

Similarly, there is a robust literature on ecological functions that contribute to agroecosystem resilience, resulting in a number of indicator frameworks that identify or quantify ecological processes that stabilize farms faced with shocks (Büchs, 2003; Cabell and Oelofse, 2012; Callo-Concha and Ewert, 2014). In the most extensive agroecosystem-specific indicator framework for resilience to date (Cabell and Oelofse, 2012), the authors offer a suite of 13 social and ecological indicators derived from a review of the resilience literature. While this list is extensive, there are no nutrition-specific indicators, nor are there any direct measures of household food security, diet diversity, or diet quality incorporated into the framework (Cabell and Oelofse, 2012).

This trend holds across indicator frameworks for agricultural and livelihood resilience, which lack an explicit link between ecosystem nutrient availability and provisioning for human nutrition at the household level (Prosperi et al., 2016; Quinlan et al., 2016). Related work has addressed tradeoffs and synergies between agricultural yield and ecosystem services (SteffanDewenter et al., 2007; Bennett et al., 2009; Nelson et al., 2009); however, direct links to the underlying biophysical conditions and nutrient cycling regulated by farm management have not been made explicit in these frameworks. Additionally, more complex measures of nutritional provisioning that go beyond crop yield or market value are needed to fully capture resilience 
dynamics at the level of the agroecosystem (DeClerck et al., 2011; Remans et al., 2011; Wood, 2018).

A standard set of indicators for nutrition is the Food and Agriculture Organization's (FAO) four dimensions of food security: availability, access, utilization, and stability (FAO, 2008). As defined in the 1996 World Food Summit, food security is "physical and economic access to sufficient safe and nutritious food that meets [one's] dietary needs and food preferences for an active and healthy life" (FAO, 2008). The idea that adequate nutrition, and not only sufficient caloric intake, is required for long-term health is an important aspect of the FAO's definition and therefore critical to nutrient provisioning at the agroecosystem level (Jones et al., 2016). To relate ecological and nutritional functions of agroecosystems, then, food security and nutritional indicators should be integrated into frameworks for social-ecological resilience.

\section{Indicators Linking Ecological and Nutritional Functions of Agroecosystems}

We developed an indicator framework that pairs ecological and nutritional indicators of agroecosystem function (Table 1). Specifically, we conducted a literature review and selected ecological and nutritional indicators with demonstrated importance for agroecosystem functions and resilience in prior theoretical and empirical work. We then paired indicators based on known relationships between underlying ecological and nutritional functions. Finally, we linked the selected indicators to farm management strategies, coping, and adaptive capacity in smallholder agroecosystems. We tested potential metrics (i.e., measures of each indicator) for agroecosystem functions by applying the indicator framework to a case study, described below. Results from the case study demonstrate the utility of the framework and could be used to refine or adapt indicators and their measures in an iterative process of metric development and data analysis.

The literature review and paired indicator approach resulted in four pairs of ecological and nutritional indicators measurable at the agroecosystem level. Here, an agroecosystem is defined as the social and ecological components of a farm, including all land and species managed by a farm household. Our framework could apply to larger scales, such as landscapes or regions, but the conceptual framing and case study data presented in this paper are at the agroecosystem level. Researchers could use these indicators of agroecosystem function to support smallholders to adapt agricultural practices based not only on their ecological impacts but also their contributions to, or tradeoffs with, household nutritional needs.

Though they do not directly measure outcomes for human nutritional status, "nutritional" indicators in our framework relate conceptually to the FAO's four dimensions of food security: availability, access, utilization, and stability (FAO, 2008). These proxy measures enable relatively simple data collection and analysis compared to more complex, direct measures that may be less feasible in low-resourced contexts. Each of our indicator pairs aligns with one dimension of food security, offering proxies for food availability, access, and utilization, and tying them to ecological functions that may underlie their stability (Table 1). In line with the FAO dimensions, our framework integrates stability as a subcomponent of all other indicators rather than as its own indicator. We also incorporate both the quality and nutritional functional diversity of diets to offer a more comprehensive understanding of food "utilization."

Productivity. Total crop production per area (1E) and staple food availability (1N) are paired as Productivity indicators. Total crop production per area, or total yield, is broadly defined as the amount of food produced per harvested area. The ability of an agroecosystem to maintain productivity over time, even in the face of disturbance or environmental variability is called yield stability (Pimm, 1984; Raseduzzaman and Jensen, 2017). Sustained crop production indicates that soil fertility and associated nutrient cycling processes are functioning and able to produce staple crops for farm households. Many smallholders cultivate staples for direct household consumption, even when local markets are available (Isakson, 2009; Oyarzun et al., 2013). Therefore, this ecological indicator links to staple food availability, an indicator that represents the baseline nutritional (caloric) function of agroecosystems. Staple food availability can be defined as the capacity of a smallholder agroecosystem to provide sufficient quantities of staple crops to meet household caloric needs (FAO, 2008). This indicator is particularly relevant in smallholder systems, where a single crop (such as maize in Guatemala) can make up the majority of the diet (Fuentes Lopez, 2005). In the case of staple grains, Productivity generally supports caloric sufficiency of diets but may not guarantee nutrient sufficiency, necessitating indicators 2-4. Productivity indicators relate to the FAO dimension of food availability (FAO, 2008).

Diversity. Crop diversity (2E) and access to a diversified diet $(2 \mathrm{~N})$ are paired as Diversity indicators. An agroecosystem with crop diversity contains species that fill distinct ecological niches. Crop species can vary over time, such as when cover crops are grown between harvested food crops in a rotation (Snapp et al., 2005), or species may overlap in space, through intercropping, for example. Diversified crop production in space and time contributes to long-term crop productivity (Vandermeer, 1989) and ensures household access to multiple types of crops at any given time of year, which is why it is paired with household access to a diversified diet. Access to a diversified diet is defined as on-farm availability of a diverse selection of edible crops whose nutritional complementarity increases diet quality (Remans et al., 2012; Jones, 2016) and is best measured using standardized methods of diet diversity (i.e., Minimum Dietary Diversity for Women, Dietary Diversity Score, or Food Variety Score). A diversified diet complements staple crop availability, as food availability is necessary but insufficient to complete a healthy diet. Households may gain access to a diversified diet by growing diverse crops, purchasing diverse crops, or through a combination of growing and purchasing foods (Jones, 2017). In smallholder contexts where markets remain inaccessible or unreliable, such as in our case study region, edible crop diversity is a robust indicator of access to a diverse diet. Diversity indicators relate to the FAO dimension of food access.

Quality. Beneficial species interactions (3E) and edible crop quality $(3 \mathrm{~N})$ are paired as Quality indicators. Farmers can 
TABLE 1 | Indicator framework for ecological and nutritional functions of agroecosystems.

\begin{tabular}{|c|c|c|c|}
\hline Indicator pair & $\begin{array}{l}\text { Ecological }(E) \text { or } \\
\text { nutritional }(\mathrm{N})\end{array}$ & Indicator & Agroecosystem function \\
\hline \multirow[t]{2}{*}{$\begin{array}{l}1 \\
\text { Productivity }\end{array}$} & $E$ & Total crop production per area & $\begin{array}{l}\text { Produce crops over time and under variable environmental } \\
\text { conditions }\end{array}$ \\
\hline & $\mathrm{N}$ & Staple food availability & $\begin{array}{l}\text { Supply sufficient quantities of staple crops to meet household } \\
\text { caloric needs }\end{array}$ \\
\hline \multirow[t]{2}{*}{$\begin{array}{l}2 \\
\text { Diversity }\end{array}$} & $E$ & Crop diversity & $\begin{array}{l}\text { Fill distinct ecological niches and contribute to long-term } \\
\text { productivity by varying crop species over time and in space }\end{array}$ \\
\hline & $\mathrm{N}$ & Access to a diversified diet & $\begin{array}{l}\text { Provide access to diverse food crops, potentially impacting diet } \\
\text { quality }\end{array}$ \\
\hline \multirow[t]{2}{*}{$\begin{array}{l}3 \\
\text { Quality }\end{array}$} & $E$ & Beneficial species interactions & $\begin{array}{l}\text { Facilitate crops' nutrient uptake, growth, and reproduction through } \\
\text { beneficial interactions within and between trophic levels }\end{array}$ \\
\hline & $\mathrm{N}$ & Edible crop quality & $\begin{array}{l}\text { Increase crop nutrient content and elicit phytochemical responses } \\
\text { through facilitative species interactions, improving crop nutritional } \\
\text { quality for human diets }\end{array}$ \\
\hline \multirow[t]{2}{*}{$\begin{array}{l}4 \\
\text { Functional Diversity }\end{array}$} & $E$ & $\begin{array}{l}\text { Functional diversity and } \\
\text { redundancy }\end{array}$ & $\begin{array}{l}\text { Enable a functional safety net by planting crops with diverse } \\
\text { ecological functional traits and levels of associated non-crop } \\
\text { species diversity }\end{array}$ \\
\hline & $\mathrm{N}$ & Nutritional functional diversity & $\begin{array}{l}\text { Fulfill nutritional needs for household diets by growing crop } \\
\text { species that provide complementary and diverse nutrients }\end{array}$ \\
\hline
\end{tabular}

Indicators were adapted from prior frameworks, including Cabell and Oelofse (2012), the EC-FAO food security framework (FAO, 2008), and the sustainable diets literature (e.g., Allen et al., 2014).

foster beneficial species interactions within and between trophic levels by planting species known to facilitate other crops' growth and reproduction, such as growing leguminous crops alongside grasses or other non-legumes to stimulate nutrient uptake (Li et al., 2016), maintaining flowering species and natural vegetation on farms to attract pollinators (Garibaldi et al., 2013), or using ecological pest management (e.g., pushpull techniques) (Letourneau et al., 2011). As has been wellcharacterized in natural ecosystems in fields such as chemical ecology (Hunter, 2016b), these interspecific and inter-trophic interactions can affect the yield and nutrient content of harvested crops that contribute to household diets (Ahmed and Stepp, 2016; Dainese et al., 2019). Edible crop quality is a measure of the concentrations of crop nutrients important for human nutrition that vary based on environmental and management factors (Ahmed and Stepp, 2016). Positive species interactions enhance edible crop quality by increasing nutrient availability and uptake, such as through facilitation, niche partitioning, and increased nutrient use efficiency in multi-cropped systems (Zhang and Li, 2003; Brooker et al., 2015). They can also elicit phytochemical responses that may impact crop secondary metabolite concentrations relevant to human diets (Liu, 2003; Brandt et al., 2011; Hunter, 2016a). In agricultural landscapes with degraded or low-fertility soil, crop nutritional quality can decline sharply (Lal, 2009); it is therefore important, especially in regions with micronutrient deficiencies, including Guatemala, to consider management approaches that could improve the quality and not just the quantity of crops produced (Watson et al., 2012). In addition to management approaches, increasing protein or micronutrient concentrations in staple crops is a major goal of biofortification and other breeding initiatives aiming to improve diet quality beyond caloric sufficiency to reduce malnutrition
(White and Broadley, 2009; Gunaratna et al., 2010). Quality indicators relate to the FAO dimension of food utilization.

Functional Diversity. Ecological functional diversity and redundancy (4E) and nutritional functional diversity (4N) are paired as Functional Diversity indicators. Ecological functional diversity and redundancy occur when an agroecosystem contains multiple crop types with differing functional traits, but with enough overlap in traits to provide an ecological safety net should one crop fail (Moonen and Bàrberi, 2008; Martin and Isaac, 2015; Wood et al., 2015). Increased crop diversity, the planned component of biodiversity, also increases associated (noncrop) biodiversity, which can further enhance agroecosystem functions, as well as buffering capacity and resilience (Altieri, 1999; Elmqvist et al., 2003). A mix of crops that encompasses distinct ecological functions (e.g., annual and perennial species) is also more likely to contribute to a broad range of nutrient requirements, represented here by the nutritional functional diversity indicator. Nutritional functional diversity is defined as the degree to which an agroecosystem fulfills nutritional functions for household diets by providing complementary and diverse nutrients across species on the farm (DeClerck et al., 2011; Luckett et al., 2015; Wood, 2018). Unlike the Diversity and Quality indicators, nutritional functional diversity accounts for the complete suite of nutrients present in different crop types, and evaluates the amounts, diversity, and evenness of nutrients across an agroecosystem, given human nutrient intake requirements (i.e., dietary reference intakes) (Remans et al., 2011). For example, out of two farms that have the same edible crop diversity (species richness $=3$ for each farm), a farm that produces maize, beans (protein-rich), and sweet potato (high in vitamin A) offers greater nutritional functional diversity and can better meet nutritional requirements than does a farm that grows maize, cassava, and 
rice, all of which are carbohydrate-rich staple crops (DeClerck et al., 2011). Functional Diversity indicators relate to the FAO dimension of food utilization.

\section{CASE STUDY APPLICATION}

\section{Case Study Selection}

We tested our indicators for ecological and nutritional functions using data from a case study in a rural region of eastern Guatemala (Figure 2). The case study combined interview data with analysis of protein content of maize from farms to identify the status of ecological and nutritional functions of smallholder agroecosystems in the region, as well as interactions between functions. Our aim was to identify how interactions between ecological and nutritional indicators affect trends in agroecosystem function and resilience. While the metrics in the Guatemalan case study are site-specific, the indicator framework is designed to be both generalizable and adaptable to facilitate applications in other systems and regions.

Nationally, Guatemala suffers from the double burden of malnutrition, with the second highest global rate of childhood stunting (49\%) and the highest rate in Latin America, along with growing presence of overweight and obesity (50\% in women of reproductive age) (Black et al., 2008). These nutritional outcomes are closely correlated with poverty and ethnicity. Over 75 percent of Guatemala's indigenous population falls below the poverty line (Bygbjerg, 2012). According to national census data, indigenous peoples compose nearly 40 percent of the population (Instituto Nacional de Estadística, 2013). Of those, 7.6 percent are Q'eqchi' Maya, the primary sample population for this study.

The case study took place in the highly remote, eastern lowland region of Guatemala called Sarstún, in the Izabal department (Figure 2). Sarstún is an isolated and data-poor region with informal governance structures and few institutional resources. Tropical secondary forests, mangroves, subsistence farms, and small-scale fisheries characterize the hilly, coastal landscape. The forested areas bordering the Sarstún River were designated as a national protected area-the Sarstún River Multiple Use Area (SRMUA)-in 2005. However, due to its remoteness, few administrative resources have reached the majority-indigenous communities that reside there. The total population of the SRMUA is estimated to be slightly more than 4,000 people, distributed across 21 agricultural communities, the majority of whom (78\%) are Q'eqchi' Maya (Coadministración, 2009).

Landscape trends in eastern Guatemala include local migration to the region, increased large-scale investments and acquisitions of land for cattle and palm oil plantations (i.e., "land grabbing"), and generalized degradation due to increasing pressure on forest resources (Alonso-Fradejas, 2012; Grandia, 2012). In SRMUA smallholder agroecosystems, as with approximately $65 \%$ of the Latin American farming population (Berdegué and Fuentealba, 2011), household nutrition is primarily dependent on local crop production and malnutrition is prevalent. With heightened pressures on land from both internal and external forces, Q'eqchi' smallholders and their agroecosystems are increasingly vulnerable to losses in both ecological and nutritional functions and decreased resilience in the face of shocks. This combination of contextual factors makes the SRMUA an appropriate test case for our ecological and nutritional indicator framework, as it can be used to identify and evaluate management practices that affect resilience on smallholder farms.

\section{Data Collection and Analysis}

Our sample included eleven villages (52\% of total villages) and 60 households $(\sim 10 \%$ of total population) in SRMUA, selected through a randomized sampling scheme in communities with ties to the local sustainable rural development non-profit APROSARSTUN (the Mayan Association for Rural Well-being in the Sarstún Region, Spanish acronym). We conducted semistructured farmer interviews with 60 Q'eqchi' farmer households, from which we derived both categorical and continuous response variables for indicator analysis. We also analyzed maize samples from each household for nitrogen and protein concentrations, the case study metric (measure of the broader indicator) for edible crop quality in our framework application.

Interviews focused on maize production and household management of cornfields (milpas), along with discussion of crop outcomes and biophysical change over time (e.g., yield stability and soil fertility). Interviews were conducted either in Spanish (60\%) or in Q'eqchi' Mayan through a translator. APROSARSTUN provided field assistants and translators for the study, which may have influenced farmer responses to questions regarding agroecological management practices, though precautions were taken to ensure unbiased responses. Four key informant interviews were also conducted with APROSARSTUN staff members to contextualize interview results and better define appropriate ecological and nutritional metrics for the case study. All interview guides and study materials were reviewed by the Tufts University Social, Behavioral, and Educational Research Institutional Review Board and were given exempt status under IRB study \# 1403034. We received verbal consent from all participating members of each household prior to conducting interviews and collecting samples. The semi-structured interview questionnaire is available in Appendix 2.

Representative maize samples from the most recent harvest were collected from households following the interview $(n=55)$. Five households were unable to provide maize samples for the study, either because they only had access to purchased maize at home (not grown on their land) or because they did not have access to their grain storage at the time of the interview. Maize was then nixtamalized following a method first described by Bressani and Scrimshaw (1958); briefly, maize samples were heated in a $4 \%$ calcium hydroxide $\left(\mathrm{Ca}(\mathrm{OH})_{2}\right)$ solution at $94^{\circ} \mathrm{C}$ for $50 \mathrm{~min}$, removed from the heat and left to stand for $14 \mathrm{~h}$, washed, and transferred to a lyophilizer for $48 \mathrm{~h}$ to dry prior to grinding with a ball mill (Kleco). Ground samples were analyzed for \% nitrogen by dry combustion in a CHNOS analyzer (vario MICRO cube, Elementar Americas, Mt. Laurel, NJ, USA) with L-Glutamic acid standards. Percent nitrogen was converted to maize \% protein by multiplying by a conversion factor of 6.25 (Galicia et al., 2009). 


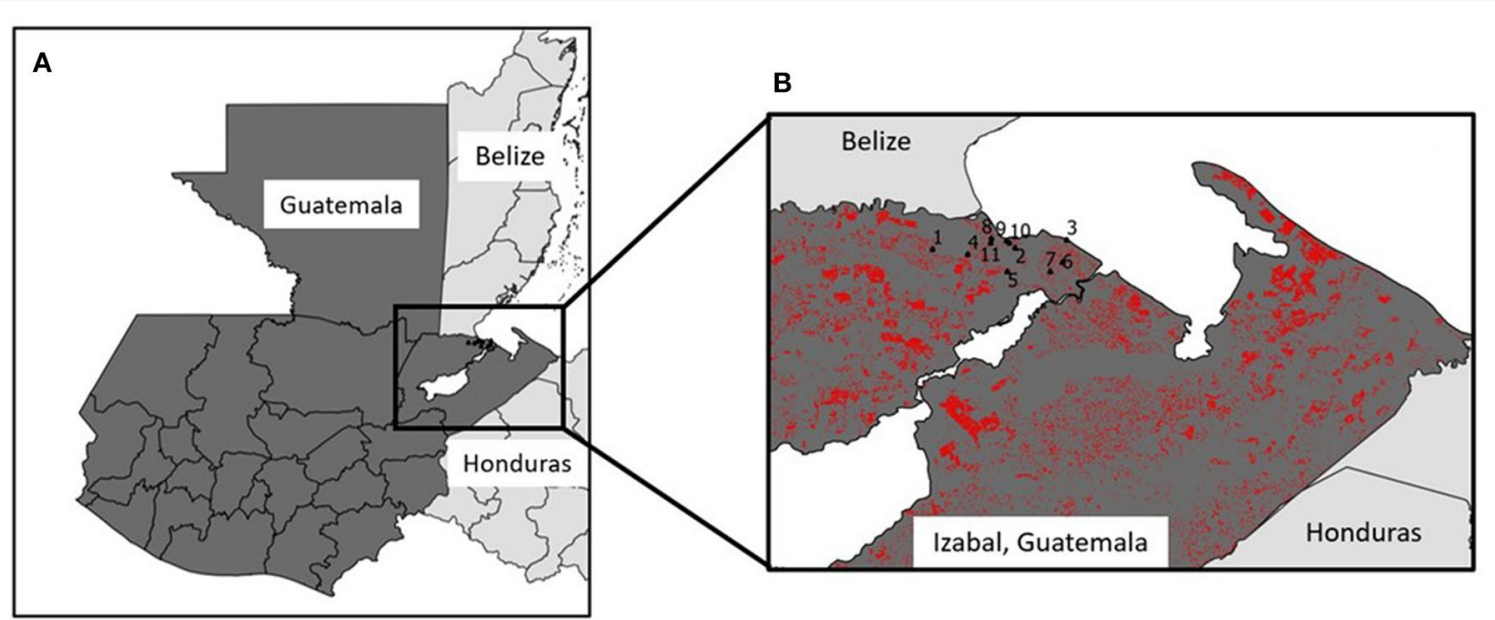

FIGURE 2 | Map of case study location and villages sampled in the Izabal Department of Guatemala. (A) Shows Guatemala alongside its neighboring countries of Belize and Honduras, both of which are adjacent to the study site shown in the inset map. (B) Shows a closer view of the eleven villages included in the case study, which are located in the Sarstún Region of Guatemala just south of the Sarstún River, which forms the border with Belize. Red pixels on the inset map represent forest loss from 2000-2014, the year that interviews were conducted. Source: Hansen/UMD/Google/USGS/NASA.

\section{Indicators and Statistical Analysis}

Table 2 provides an overview of how case study data were converted into metrics used in the indicator framework. Because we used an existing dataset to test the framework, we were unable to include diet diversity data, which was not a component of the original study questionnaire (Appendix 2). Based on available data, we tested three of the four paired indicators (Productivity, Quality, and Functional Diversity, but not Diversity) in our case study. Reflecting the difficulty of acquiring fine-scale quantitative data in the case study region (e.g., on crop yields), the majority of case study variables were categorical, with the exception of crop species richness data used to calculate ecological and nutritional functional diversity (Functional Diversity indicators), which were continuous. We therefore transformed all raw data into categorical variables with three levels $(0,+1,-1)$ to give each metric equal weight within the framework.

Categorical values of $0,+1$, and -1 were assigned to each farm household for each indicator, representing the neutral, positive, or negative status of a given indicator on farms. For each case study variable, we determined the range for a negative, neutral, or positive status using the following approach: (1) if there was a standard or mean value or range of values considered "sufficient" in the literature (e.g., mean protein concentration in maize from the FAO), we made this the 0 or "neutral" value; however, (2) if there was a clear scientific rationale for an indicator (e.g., high crop diversity is more ecologically beneficial than low crop diversity) but no way to quantify a "neutral" value, we scaled indicator values relative to the maximum value in the sample. This approach enabled us to determine the relative status of agroecosystem functioning on farms, given regional conditions, and to identify the most marginalized or vulnerable farms as well as those with relatively improved outcomes (and their associated management practices). Summary statistics for the raw data from the case study are presented in Appendix 1 (Table A1.1), along with distributions of all raw data used to define case study metrics and their assigned categories for analysis (Figure A1.1).

To demonstrate the potential of the indicator framework to analyze data at a finer resolution-where such data is available for smallholder agroecosystems-we conducted a more detailed analysis of ecological and nutritional functional diversity (Functional Diversity indicators) using continuous rather than categorical values. We tested for a relationship between the Functional Diversity indicators using simple linear regression. To quantify ecological functional diversity of agroecosystems (i.e., crop functional diversity), we used the open software platform FDiversity (Casanoves et al., 2011) to calculate Rao's Quadratic Entropy $(\mathrm{Q})$ based on crop species richness and area data for each farm (Botta-Dukat, 2005; Schleuter et al., 2010) (Table A3.1). Crops were evaluated for key plant functional traits by determining their binary (yes or no) associations with each of the following functional categories: perennial, C3 grass, C4 grass, forb or broadleaf, nitrogen-fixing, woody, and vining/groundcover (Table A3.2). Similarly, to calculate nutritional functional diversity, we used average concentrations and dietary reference intakes of 17 essential dietary nutrients in the 29 food crops cultivated by farmers in the sample, along with crop-specific area data for each farm (Tables A3.3, A3.4) (Remans et al., 2011). FDiversity software was also used to calculate Rao's Q values for nutritional functional diversity measures. Although agrobiodiversity data was an initial input for calculating both ecological and nutritional functional diversity indicators, this data was processed with functional group (for ecological functional diversity) and nutrient data (for nutritional functional diversity) for each crop prior to analysis and metric calculation for the case study. All functional traits were weighted on an equal basis in the analysis.

After quantifying all indicators for our sample through the above metrics, we evaluated relationships between farm 
TABLE 2 | Indicators of ecological and nutritional functions applied to a case study of smallholder agroecosystems in eastern Guatemala.

\begin{tabular}{|c|c|c|c|c|c|}
\hline Indicator pair & $\begin{array}{l}\text { Ecological }(E) \text { or } \\
\text { nutritional }(N)\end{array}$ & Indicator & Case study metric & Metric calculation & Interview question (translated) \\
\hline \multirow[t]{2}{*}{$\begin{array}{l}1 \\
\text { Productivity }\end{array}$} & $E$ & $\begin{array}{l}\text { Total crop } \\
\text { production per unit } \\
\text { area }\end{array}$ & Crop yield over time & $\begin{array}{l}\text { Neutral }(0) \text {, increasing } \\
(+1), \text { decreasing }(-1)\end{array}$ & $\begin{array}{l}\text { Have you seen a difference in the } \\
\text { productivity of your cornfields } \\
\text { ("milpas") since you began farming } \\
\text { here? If so, how has it changed (has it } \\
\text { increased, decreased, or stayed the } \\
\text { same), and why? }\end{array}$ \\
\hline & $\mathrm{N}$ & $\begin{array}{l}\text { Staple food } \\
\text { availability }\end{array}$ & $\begin{array}{l}\text { Deficit/surplus maize } \\
\text { yield }\end{array}$ & $\begin{array}{l}\text { Sufficient maize for } \\
\text { household }(0) \text {, sells maize } \\
(+1) \text {, buys maize }(-1)\end{array}$ & $\begin{array}{l}\text { How much maize did you produce } \\
\text { last year, and what percent of it went } \\
\text { feed your household? Was it sufficient } \\
\text { to feed your household? If there was } \\
\text { maize remaining, how much of it did } \\
\text { you sell or exchange? }\end{array}$ \\
\hline \multirow[t]{2}{*}{$\begin{array}{l}2 \\
\text { Diversity }\end{array}$} & $E$ & Crop diversity & Agrobiodiversity & $\begin{array}{l}\text { 4-6 species }(0), 7 \text { or more } \\
\text { species }(+1), 0-3 \text { species } \\
(-1)\end{array}$ & $\begin{array}{l}\text { How many crops do you plant during } \\
\text { the main growing season? What } \\
\text { about the dry season } \\
\text { ("matahambre")? (prompt with list of } \\
\text { crops, if needed) }\end{array}$ \\
\hline & $N$ & $\begin{array}{l}\text { Access to a } \\
\text { diversified diet }\end{array}$ & $\begin{array}{l}\text { (not measured in } \\
\text { case study) }\end{array}$ & - & - \\
\hline \multirow[t]{2}{*}{$\begin{array}{l}3 \\
\text { Quality }\end{array}$} & $E$ & $\begin{array}{l}\text { Beneficial species } \\
\text { interactions }\end{array}$ & Multi-cropping & $\begin{array}{l}\text { Multiple crops in } \\
\text { monoculture }(0) \text {, multiple } \\
\text { crops in polyculture }(+1) \text {, } \\
\text { single crop in monoculture } \\
(-1)\end{array}$ & $\begin{array}{l}\text { Do you grow more than one crop? If } \\
\text { so, do you plant your crops together } \\
\text { in the same field, or in separate fields? }\end{array}$ \\
\hline & $N$ & Edible crop quality & $\begin{array}{l}\text { Maize protein } \\
\text { concentration }\end{array}$ & $\begin{array}{l}\text { Average maize } \% \text { protein } \\
\text { range from FAO }(8-11 \%) \\
(0),>11 \% \text { protein }(+1) \\
<8 \% \text { protein }(-1)\end{array}$ & $\begin{array}{l}\text { Do you have any white corn cobs } \\
\text { from your last harvest? Would it be } \\
\text { possible for me to take some grains } \\
\text { from your corn as a sample to test its } \\
\text { nutrients? }\end{array}$ \\
\hline \multirow[t]{2}{*}{$\begin{array}{l}4 \\
\text { Functional Diversity }\end{array}$} & $E$ & $\begin{array}{l}\text { Functional diversity } \\
\text { and redundancy }\end{array}$ & $\begin{array}{l}\text { Crop functional } \\
\text { diversity }\end{array}$ & $\begin{array}{l}\text { Rao's Quadratic Entropy } \\
\text { (Q) of } 1.87-3.83(0), Q \text { of } \\
3.84 \text { and above }(+1), Q \text { of } \\
0-1.86(-1) \text { (quantile } \\
\text { cutoffs) }\end{array}$ & $\begin{array}{l}\text { What is the total planted area of each } \\
\text { crop you grow? (prompt with list of } \\
\text { crops) }{ }^{*}\end{array}$ \\
\hline & $N$ & $\begin{array}{l}\text { Nutritional functional } \\
\text { diversity }\end{array}$ & $\begin{array}{l}\text { Nutritional functional } \\
\text { diversity }\end{array}$ & $\begin{array}{l}\text { Rao's Quadratic Entropy } \\
\text { (Q) of } 0.0057-0.013(0), Q \\
\text { of } 0.014 \text { and above }(+1) \text {, } \\
\text { Q of } 0-0.0056(-1) \\
\text { (quantile cutoffs) }\end{array}$ & $\begin{array}{l}\text { What is the total planted area of each } \\
\text { crop? (prompt with list of crops) }\end{array}$ \\
\hline
\end{tabular}

${ }^{\star}$ Raw data were subsequently transformed using crop functional trait data prior to analysis (Table A3.2).

${ }^{\star}$ Raw data were subsequently transformed using crop nutrient data prior to analysis (Tables A3.3, A3.4).

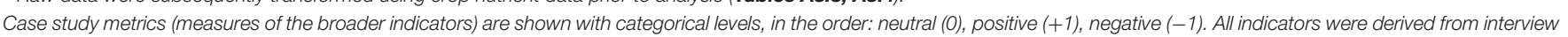

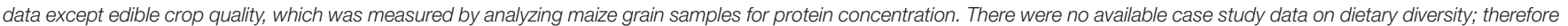

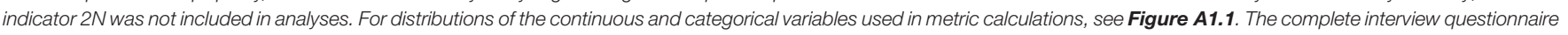
can be found in Appendix 2.

management practices and ecological and nutritional functions of agroecosystems in two steps. First, we created an integrated Agroecosystem Function Index (AFI) for each farm using ecological and nutritional indicators in our framework. We quantified the overall agroecosystem functioning of each farm in the case study as a single number between -6 and +6 (the range would be -8 to +8 for all four pairs of indicators). AFIs were derived by summing all values $(0,+1$, and -1$)$ for the three ecological and three nutritional indicators for a given farm household, resulting in a cumulative positive, negative, or zero (neutral) value. AFI values closer to +6 or -6 indicated stronger positive or negative functional states on farms, respectively.
Then, to evaluate tradeoffs and synergies between pairs, we summed the coded values $(0,+1,-1)$ for each ecologicalnutritional indicator pair on each farm and used contingency analysis to test the null hypothesis that each pair of variables was independent across farms (Table 4A). Using 15 contingency tables, we then analyzed the level of co-occurrence (synergy) or existence of opposite trends (tradeoffs) between ecological and nutritional functions in pairs and non-pairs across all farms in the sample (Tables $4 \mathrm{~B}, \mathrm{C}$ ).

Finally, we complemented our quantitative analysis with qualitative analysis of interview data, operationalizing our indicator framework to assess smallholder resilience. For this 
analysis, we used coded interview data to identify communitylevel and idiosyncratic shocks on farm households in our sample. Farmers' demonstrated abilities to respond to these shocks were categorized into coping and adaptive capacities. Coping capacities were defined as strategies that enabled farm households to persist in agriculture without qualitative changes to the structure of the agroecosystem. Adaptive capacities were defined as farmer changes to agroecosystem management meant to increase flexibility and improve outcomes in the face of shocks. Farms that showed both coping and adaptive capacities were considered adaptive. Adaptive farm management strategies were categorized into three groups: ecological, market-oriented, and hybrid strategies. Ecological strategies included maintaining high levels of soil cover, using nitrogen-fixing perennial and annual species to replenish soil fertility, growing a diversity of crops, and refraining from burning farm fields. Marketoriented strategies included growing hybrid maize varieties in monoculture, applying higher rates of herbicides, insecticides, and inorganic fertilizers, and focusing production on a smaller number of crops to bring to market. Hybrid approaches included increasing the diversity of perennial tree crops to sell to specialty markets, as well as other combinations of agrichemical application and use of nitrogen-fixing plant species. As a test of the framework's ability to assess agroecosystem functionresilience dynamics, we quantified relationships between farmer coping and adaptive capacities and ecological and nutritional indicator values on farms using analysis of variance (ANOVA) models, described below. Following previous definitions of resilience capacities (Béné et al., 2012), transformative capacities could also be assessed using the framework. However, there was not sufficient evidence of transformative capacity in the sample to include it in our analysis. Transformative management strategies could include conversion from traditional crops to a novel production system or migration to an urban environment, for example.

Data were analyzed using R software (version 3.6.2, "Dark and Stormy Night”) (R Core Team, 2019). We used a Kendall's tau rank correlation to assess the association between ecological and nutritional components of the AFI across farms. McNemar's Chisquared tests were run on contingency tables corresponding to each of the ecological and nutritional indicator pairs, with the exception of Functional Diversity indicators, which had a high number of neutral (0) values and required a Fisher's Exact test (Tables 3, 4). We assessed the relationship between our ecological and nutritional Functional Diversity indicators using a simple linear regression model with the $\mathrm{lm}$ function in $\mathrm{R}$ ( $\mathrm{R}$ Core Team, 2019). Also in R, we performed ANOVA followed by Tukey's Honestly Significant Difference post-hoc tests to assess statistical differences in ecological and nutritional indicator values on farms. One set of analyses focused on shocks and a second set analyzed coping and adaptive capacities. We used three separate mixed-effects models for each of these analyses, each of which included either the AFI (sum of ecological and nutritional indicators per farm), the nutritional component of the AFI (sum of nutritional indicators per farm), or the ecological component of the AFI (sum of ecological indicators per farm) as the response variable. Shock type and capacity type were the main effects in the two sets of analyses, respectively, with village as a random effect in all models. We explored the community-level shock of land-grabbing using a separate ANOVA model with no random effect, comparing farms in villages that did or did not have a land grab according to interview data. Ninety-five percent confidence intervals were used to assess statistical significance.

\section{Case Study Results Synergies and Tradeoffs Between Ecological and Nutritional Indicators}

At the agroecosystem level, case study data showed a positive relationship between ecological and nutritional functions. There was a significant and positive rank correlation between the ecological and nutritional components of the AFI across farms [Kendall's tau $=0.58, z=5.7, p<0.0001$ for $\operatorname{sum}(\mathrm{E})$ and $\operatorname{sum}(\mathrm{N})]$. This means that farms with positive levels of functioning based on ecological indicators were significantly more likely to also have higher values for nutritional indicators, and vice-versa.

Analyses of individual case study indicator pairs, however, showed both significant positive (synergistic) and negative (tradeoff) relationships (Table 3). Across all farms, there were positive and neutral relationships between ecological and nutritional indicators for indicators 3 and 4 (Quality and Function), but there were tradeoffs within pairs for indicator 1 (Productivity). Our more detailed analysis of Functional Diversity indicators showed a strong positive relationship between ecological and nutritional functional diversity across farms in the sample ( $n=60$ farms, adjusted $R^{2}=0.74, \mathrm{~F}=171.6$ on 1 and $58 \mathrm{df}, p<0.0001)$. This result provides evidence that higher crop functional diversity on smallholder farms increases the likelihood that farms will also produce crops that offer a diverse array of essential nutrients in amounts relevant to human dietary adequacy (Wood, 2018).

Negatively correlated indicator pairs provided evidence that certain shocks and farmer responses to them led to tradeoffs between ecological and nutritional functions of agroecosystems in the Guatemalan case study (Table 3 ). Tradeoffs could signify a time lag between ecological degradation and negative nutritional functions (e.g., malnutrition), as well as the coping capacity of smallholder farm households, including by using off-farm labor to supplement income and purchase food when soil degradation leads to low agroecosystem yields (Vanek and Drinkwater, 2013). Case study results for Productivity indicators, for example, suggest that despite declining yields in the majority of study households, most farms still produced sufficient maize to sell some surplus to neighbors (Tables 2, 3). Tradeoffs between positive nutritional indicators and negative ecological indicators may reflect management strategies that increase yields or food provisioning in the short term but degrade the natural resource base over time (Table 5).

In addition to testing the indicator pairs in the framework, we also tested relationships across the full set of indicators and found that $67 \%$ of indicator combinations (ecological-nutritional, ecological-ecological, and nutritional-nutritional) were nonindependent (i.e., were related) according to McNemar's Chisquared and Fisher's Exact Tests (Table 4B). Although many 


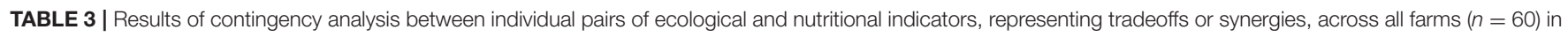
a case study in eastern Guatemala.

\begin{tabular}{|c|c|c|c|c|c|c|}
\hline Indicator & Ecological metric & Nutritional metric & Test statistic $^{\dagger}$ & $d f$ & $p$-value & $\begin{array}{l}\text { Synergy or } \\
\text { tradeoff? }\end{array}$ \\
\hline $\begin{array}{l}1 \\
\text { Productivity }\end{array}$ & Crop yield over time & $\begin{array}{l}\text { Deficit/surplus maize } \\
\text { yield }\end{array}$ & 26.73 & 3 & $6.70 \times 10^{-6}$ & $\begin{array}{l}\text { Tradeoff: } \\
\text { negative ecological; } \\
\text { positive nutritional }\end{array}$ \\
\hline $\begin{array}{l}2 \\
\text { Diversity }\end{array}$ & Agrobiodiversity & $\begin{array}{l}\text { (data not available } \\
\text { for case study) }\end{array}$ & - & - & - & - \\
\hline $\begin{array}{l}3 \\
\text { Quality }\end{array}$ & Multi-cropping & $\begin{array}{l}\text { Maize protein } \\
\text { concentration }\end{array}$ & 25.67 & 3 & $1.1 \times 10^{-5}$ & Synergy \\
\hline $\begin{array}{l}4 \\
\text { Functional Diversity }\end{array}$ & $\begin{array}{l}\text { Ecological crop } \\
\text { functional diversity }\end{array}$ & $\begin{array}{l}\text { Nutritional crop } \\
\text { functional diversity }\end{array}$ & $\mathrm{N} / \mathrm{A}$ & 3 & $2.2 \times 10^{-16}$ & Synergy \\
\hline
\end{tabular}

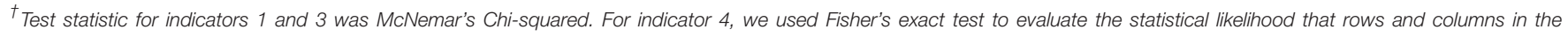
contingency table were non-independent (alternative hypothesis).

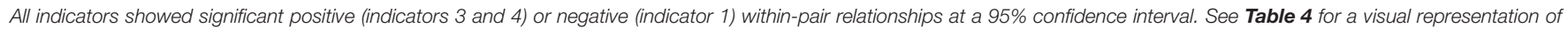
the analysis.

indicators were non-independent, only four non-paired indicator relationships had clear directionality in the contingency analysis (Table 4C). We found a weak but significant negative synergy between maize yield over time (1E; negative) and maize protein concentration ( $3 \mathrm{~N}$; neutral) $\left(\chi^{2}=26.3 \mathrm{df}=3, p=9.7 * 10^{-6}\right)$ (Table 4), indicating that both quantity and quality of maize may be affected by degradation in the case study region. There was also a significant tradeoff between maize yield over time $(1 \mathrm{E}$; negative) and multi-cropping ( $3 \mathrm{E}$; positive) $\left(\chi^{2}=26.8 \mathrm{df}=\right.$ $\left.3, p=6.5 * 10^{-6}\right)$, which could be evidence that farmers are increasing their use of beneficial species interactions as their staple crops become less productive. Finally, multi-cropping (3E) had a significantly positive association with maize protein concentration $(3 \mathrm{~N})$, and with both ecological (4E) and nutritional functional diversity $(4 \mathrm{~N})$ (Tables $4 \mathrm{~B}, \mathrm{C}$ ), meaning that farmers with higher crop functional diversity were also more likely to intercrop species, which was also positively related with crop quality. These results indicate that a holistic approach to assessing relationships across the framework could yield a more comprehensive understanding of ecological and nutritional functions of agroecosystems than indicators paired using theory and prior empirical understandings alone.

\section{Farmer Capacities Mediate Agroecosystem Functioning and Resilience to Shocks}

Agroecosystem Function Index (AFI; our proxy for the overall status and direction of combined ecological and nutritional indicators) values for the case study ranged from -6 at the lowest ( 1 farm) to 6 at the highest ( 3 farms). Most farms were characterized by a combination of positive, negative, and neutral levels of different agroecosystem functions, leading to a median AFI of 1 and a mean slightly above 0 .

We operationalized our indicator framework to examine farmers' resilience, with a focus on coping and adaptive capacities, in the face of landscape-level, community-level, and idiosyncratic household shocks. Across all villages, farmers faced the landscape-level shock of deforestation. Farmers also identified one major community-level shock: acute loss of land due to large-scale land acquisitions (or "land grabs") that reduced or eliminated land ownership in five out of eleven villages in the sample (Alonso-Fradejas, 2012). Land grabs for rubber plantations, oil exploration, and cattle ranching were cited as reasons for farmers' loss of agricultural and common lands. Idiosyncratic, or household-level, shocks were also recorded for all farms and reflected the effects of broader biophysical patterns (e.g., climate changes), community-level shocks (e.g., direct household losses of land due to land grabs), as well as more localized problems (e.g., pest pressure, low soil fertility). Primary household shocks mentioned during interviews included climate shocks (shifts in rainfall patterns and rapid temperature changes that caused crop damage), degradation of cropland (generally related to deforestation) that led to yield losses, loss of land ownership or tenure from land grabs, increased pre- and post-harvest pest pressure, and combinations of these. Only three farmers (5\% of the sample) stated that they had not experienced any changes that affected their livelihoods in the last decade, and all of these were younger farmers who had $<10$ years of experience as heads of farming households.

We used the AFI to test household response to communitylevel and idiosyncratic shocks, thereby assessing their adaptive capacity and resilience to agroecosystem disturbance. Both community-level and household-level shocks led to significant differences in indicators of agroecosystem functioning (Figure 3). Relative to the generalized landscape-level shock of deforestation, the acute shock of land grabbing led to significantly lower nutritional indicators in affected villages, driving a lower AFI and resilience on farms that had experienced land grabs (Figure 3A). Households experienced inconsistent effects of community-level shocks. Farms that experienced direct losses of land due to coupled landscape degradation and land grabbing had significantly lower nutritional indicators in the AFI than those who did not experience land losses (Figure 3B). However, there were no significant effects of household-level shocks on the overall AFI, likely due to non-significant differences in farm ecological indicators by shock type. 
TABLE 4 | Matrices showing relationships between ecological and nutritional indicators for 60 farms in the Guatemalan case study.

\begin{tabular}{|c|c|c|c|c|c|}
\hline \multicolumn{6}{|c|}{ (A) Visual representation of contingency analysis for paired indicators } \\
\hline Indicator & \multicolumn{4}{|c|}{ Contingency table } & Outcome \\
\hline 1 & -1 & 10 & 8 & 19 & Tradeoff \\
\hline \multirow[t]{2}{*}{ Productivity } & 0 & 4 & 3 & 9 & \\
\hline & 1 & 0 & 1 & 5 & \\
\hline \multirow[t]{3}{*}{ Quality } & 0 & 2 & 11 & 0 & Synergy \\
\hline & 1 & 3 & 24 & 6 & \\
\hline & & -1 & 0 & 1 & \\
\hline 4 & -1 & 18 & 2 & 0 & Synergy \\
\hline \multirow[t]{2}{*}{ Functional diversity } & 0 & 2 & 16 & 2 & \\
\hline & 1 & 0 & 2 & 18 & \\
\hline
\end{tabular}

(B) Test statistic (McNemar's $\chi^{2}$ or Fisher's Exact) and $p$-value matrix

\begin{tabular}{|c|c|c|c|c|c|c|}
\hline & $1 E$ & $3 E$ & $4 \mathrm{E}$ & $1 N$ & $3 N$ & $4 N$ \\
\hline $1 \mathrm{E}$ & NA & $\begin{array}{c}\chi^{2}=26.8 \\
p=6.5^{\star} 10^{-6}\end{array}$ & $\begin{array}{l}x^{2}=12.7 \\
p=0.005\end{array}$ & $\begin{array}{c}\chi^{2}=26.7 \\
p=6.7^{*} 10^{-6}\end{array}$ & $\begin{array}{c}x^{2}=26.0 \\
p=9.7^{*} 10^{-6}\end{array}$ & $\begin{array}{c}x^{2}=12.7 \\
p=0.0053\end{array}$ \\
\hline $3 E$ & $\begin{array}{c}x^{2}=26.8 \\
p=6.5^{\star} 10^{-6}\end{array}$ & NA & $\begin{array}{l}x^{2}=14.7 \\
p=0.002\end{array}$ & $\begin{array}{c}x^{2}=3.7 \\
p=0.3\end{array}$ & $\begin{array}{c}\chi^{2}=25.7 \\
p=1.1^{*} 10^{-5}\end{array}$ & $\begin{array}{l}x^{2}=14.31 \\
p=0.0025\end{array}$ \\
\hline $4 \mathrm{E}$ & $\begin{array}{l}x^{2}=12.7 \\
p=0.005\end{array}$ & $\begin{array}{l}x^{2}=14.7 \\
p=0.002\end{array}$ & NA & $\begin{array}{c}x^{2}=6.0 \\
p=0.1\end{array}$ & $\begin{array}{l}x^{2}=14.8 \\
p=0.002\end{array}$ & $\begin{array}{l}\text { Fisher's exact } \\
p=2.2^{\star} 20^{-16}\end{array}$ \\
\hline $1 \mathrm{~N}$ & $\begin{array}{c}\chi^{2}=26.7 \\
p=6.7^{\star} 10^{-6}\end{array}$ & $\begin{array}{r}x^{2}=3.7 \\
p=0.3\end{array}$ & $\begin{array}{c}x^{2}=6.0 \\
p=0.1\end{array}$ & NA & $\begin{array}{c}x^{2}=26.3 \\
p=8.4^{*} 10^{-6}\end{array}$ & $\begin{array}{c}\chi^{2}=5.0 \\
p=0.17\end{array}$ \\
\hline $3 N$ & $\begin{array}{c}x^{2}=26.0 \\
p=9.7^{\star} 10^{-6}\end{array}$ & $\begin{array}{c}\chi^{2}=25.7 \\
p=1.1^{*} 10^{-5}\end{array}$ & $\begin{array}{l}x^{2}=14.8 \\
p=0.002\end{array}$ & $\begin{array}{c}x^{2}=26.3 \\
p=8.4^{*} 10^{-6}\end{array}$ & NA & $\begin{array}{l}x^{2}=14.7 \\
p=0.002\end{array}$ \\
\hline $4 \mathrm{~N}$ & $\begin{array}{l}x^{2}=12.7 \\
p=0.0053\end{array}$ & $\begin{array}{l}\chi^{2}=14.3 \\
p=0.0025\end{array}$ & $\begin{array}{l}\text { Fisher's exact } \\
p=2.2^{\star} 20^{-16}\end{array}$ & $\begin{array}{l}x^{2}=5.0 \\
p=0.17\end{array}$ & $\begin{array}{l}x^{2}=14.7 \\
p=0.002\end{array}$ & NA \\
\hline
\end{tabular}

(C) Direction and outcome of indicator relationships from contingency analysis

\begin{tabular}{|c|c|c|c|c|c|c|}
\hline & $1 E$ & $3 E$ & $4 \mathrm{E}$ & $1 N$ & $3 N$ & $4 N$ \\
\hline $1 \mathrm{E}$ & NA & Tradeoff & No relationship & Tradeoff & (-) Synergy & No relationship \\
\hline $3 \mathrm{E}$ & Tradeoff & NA & (+) Synergy & No relationship & (+) Synergy & (+) Synergy \\
\hline $4 \mathrm{E}$ & No relationship & (+) Synergy & NA & No relationship & No relationship & (+/-) Synergy \\
\hline $1 N$ & Tradeoff & No relationship & No relationship & NA & (+) Synergy & No relationship \\
\hline $3 N$ & (-) Synergy & (+) Synergy & No relationship & (+) Synergy & NA & No relationship \\
\hline $4 N$ & No relationship & (+) Synergy & (+/-) Synergy & No relationship & No relationship & NA \\
\hline
\end{tabular}

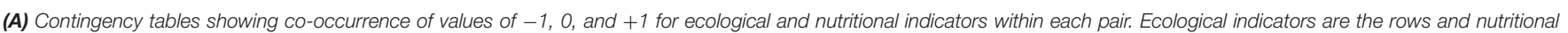

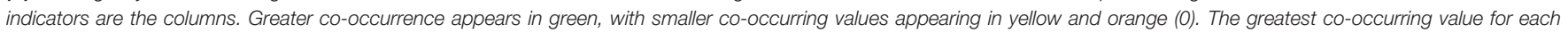

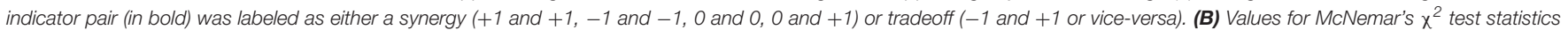

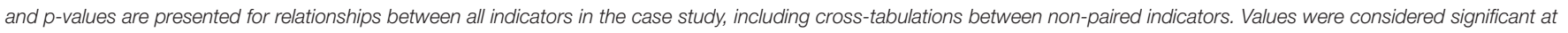

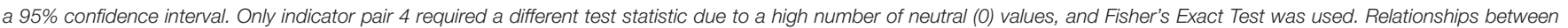

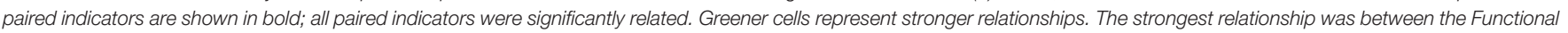

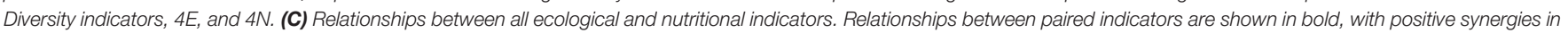

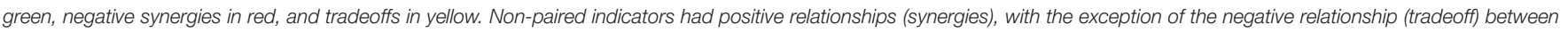
ecological Productivity (1E) and Quality (3E) indicators.

The qualitative interview analysis revealed how coping and adaptive capacities can drive differentiated outcomes in smallholder agroecosystems (Figure 4). Farms relying on coping capacities $(n=20)$ by working for or renting land from plantation owners had significantly lower ecological and nutritional indicators than farms with higher adaptive capacities $(n=40)$. While there were many distinct adaptation strategies farmers used to respond to shocks, they tended to follow either an ecological $(n=23)$, a market-oriented $(n=8)$, or a hybrid (both ecological and market-oriented; $n=9$ ) approach, as described in section Indicators and Statistical Analysis. Table 5 highlights specific management characteristics on farms that 
TABLE 5 | Coping and adaptative strategies used by farmers in the Guatemalan case study to respond to community-level and idiosyncratic shocks.

\begin{tabular}{|c|c|c|c|}
\hline $\begin{array}{l}\text { Farmer resilience } \\
\text { capacity }\end{array}$ & $\begin{array}{l}\text { Management } \\
\text { approach }\end{array}$ & Household shock type & Practices used to recover from shock \\
\hline Adaptive & Ecological $(N=23)$ & $\begin{array}{l}\text { Climate change }(N=13) \\
\text { Land degradation }(N=8) \\
\text { Pest and weed pressure }(N=8) \\
\text { Land dispossession }(N=6) \\
\text { None }(N=0)\end{array}$ & $\begin{array}{l}\text { Legume cover cropping }(N=10) \\
\text { Agroforestry }(N=8) \\
\text { Crop diversification }(N=4) \\
\text { Maize variety diversification }(N=4) \\
\text { Manual pest control }(N=3) \\
\text { Seed saving and exchange }(N=3) \\
\text { Polyculture }(N=2) \\
\text { Sustainable tourism }(N=1)\end{array}$ \\
\hline Adaptive & Market-oriented $(N=8)$ & $\begin{array}{l}\text { Climate change }(N=1) \\
\text { Land degradation }(N=4) \\
\text { Pest and weed pressure }(N=3) \\
\text { Land dispossession }(N=1) \\
\text { None }(N=1)\end{array}$ & $\begin{array}{l}\text { Hybrid and transgenic seed varieties }(N=2) \\
\text { Fertilizer use }(N=2) \\
\text { Pesticide use }(N=1) \\
\text { Grows some crops only for market (not home consumption) }(\boldsymbol{N}=\mathbf{5})\end{array}$ \\
\hline Coping & Coping $(N=20)$ & $\begin{array}{l}\text { Climate change }(N=6) \\
\text { Land degradation }(N=4) \\
\text { Pest and weed pressure }(N=6) \\
\text { Land dispossession }(\boldsymbol{N}=\mathbf{1 2}) \\
\text { None }(N=1)\end{array}$ & $\begin{array}{l}\text { Rent land from plantation owner }(N=12) \\
\text { Off-farm work on plantation }(N=7) \\
\text { Off-farm traditional work }(N=3) \\
\text { Increase farm workload of female head of household }(N=2) \\
\text { Fertilizer use }(N=1) \\
\text { Increase pesticide use }(N=6) \\
\text { Rely on communal land }(N=1) \\
\text { Purchase all maize for household consumption }(N=2)\end{array}$ \\
\hline
\end{tabular}

"Off-farm traditional work includes tasks such as fishing and practicing traditional medicine (as a "curandero") as an alternative to farming.

The number of farmers that mentioned each shock type and management practice is listed in parentheses (N). Farmers that described more than one shock or practice in response to a shock are counted multiple times. The most common shocks and practices used by farmers in each group are shown in bold.
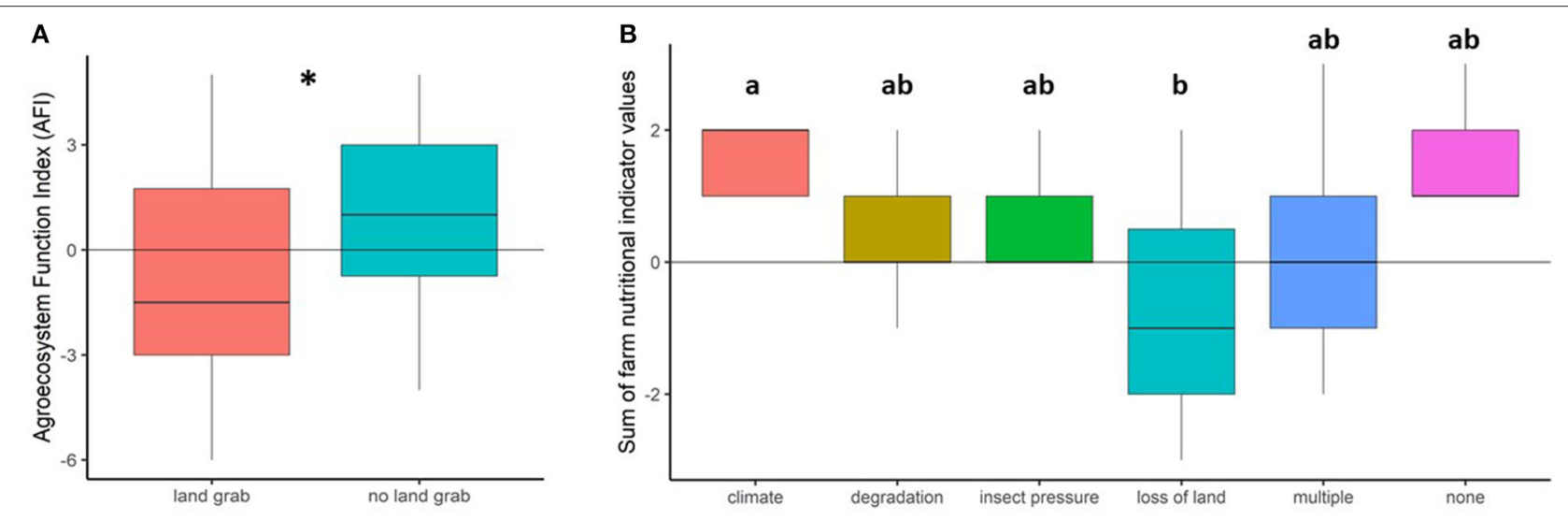

FIGURE 3 | Shocks in smallholder agroecosystems in Sarstún, Guatemala. (A) Shows the Agroecosystem Function Index (AFI) for farms experiencing a major community-level shock, land grabbing, and those subject to only generalized deforestation as a landscape-level shock (no land grab). (B) Represents the suite of household-level shocks experienced by smallholders in Sarstún and their relationships with the nutritional component of the AFI (sum of nutritional indicator values by farm). There were no significant differences by shock type for the ecological component or the overall sum of indicator values, the AFI. N=60 farms. In (A), ${ }^{*}$ Indicates $p<0.05$. In (B), different letters indicate significant differences in indicator values for distinct household shocks $(p<0.05$; Tukey's HSD). 
used coping and adaptive capacities to respond to shocks. Nearly all farms, regardless of their AFI, used some combination of these management approaches.

Ecological and hybrid adaptation strategies were associated with high AFIs, whereas market-oriented and coping strategies resulted in lower ecological and nutritional indicators (Figure 4). Ecological and hybrid approaches made use of velvet bean (Mucuna pruriens (L.) DC.), a leguminous cover crop, to improve soil fertility and ecosystem functioning for long-term crop production. In an interview, when asked his preferred way to improve soil fertility, one farmer asserted, "The most beneficial way is with velvet bean ("frijol abono," which means "fertilizer bean") because it is the most common and economical in the region, but it is growing more difficult to find the seeds because the practice is fading." Interview data confirmed that while $50 \%$ of the sample planted velvet bean at the time of the study, an additional $18 \%$ of the sample ( $68 \%$ overall) had previously used velvet bean but abandoned the practice because they now rent land or find it more difficult to save seeds to re-plant when using herbicides. Collectively, these findings suggest that adaptive capacity may be declining in the region.

Negative AFI values commonly resulted from communitylevel shocks that reduced households' adaptive capacity and ability to manage farms for improved agroecosystem functioning (Figure 4). A common example was loss of land to plantation owners ( $n=26$ farms), which led farmers to engage in coping strategies, such as decreasing their crop diversity and use of cover crops, along with shortening cycles of swidden management. These new practices reduced forest cover, which many farmers noted in interviews as a principal reason for soil fertility declines that decreased yields. One older farmer mentioned that his yields had fallen by more than $50 \%$ in his lifetime, because "before there were large areas of secondary forest that helped the soil and led to good crop yields. There are no longer mature forested areas and the soil is poor, which affects the productivity of the soil, when we burn areas with little forest cover."

Lack of land tenure also shifted farmers' management strategies toward coping when they began renting land to grow their milpas (cornfields) ( $n=19$ farms). Renting led households to reduce the number of crops and their investment in soil conservation, as farmers had little incentive to use agroecological management practices on land they did not own. One farmer commented, "Yes, I use velvet bean, but there is no true guarantee of soil conservation because my land is rented and I don't have a specific plot; I don't know which plot I'll get next year." Insecure land tenure particularly affected households that had recently immigrated to the region and those in close proximity to plantations that now own what was once community land. Farms at a greater distance from plantations also shifted their management as farmers went to work as day laborers. One such farmer explained his monoculture milpa by saying, "Now we don't have any other crops [in addition to maize] because we have to work on the plantation, which is a $3 \mathrm{~h}$ walk from here."

Market-oriented households adapted their management to shocks by growing some crops, such as hybrid or transgenic maize varieties, solely for sale on the commercial market to increase their purchasing power (Table 5). While market-oriented farms had on average higher AFI values than farmers relying on coping capacity alone, both coping and market-oriented households' AFIs were significantly lower than those from households using ecological or hybrid approaches (Figure 4). Despite evidence of coping and adaptive capacities in the face of changing landscape conditions, the capacity of smallholders to transform their agroecosystems as they underwent community-level and idiosyncratic shocks appeared limited in the case study.

\section{DISCUSSION}

Sustaining or enhancing ecological and nutritional functions of agroecosystems is necessary to foster the adaptive capacity and resilience of smallholders. To this end, our study paired ecological and nutritional indicators of agroecosystem function in a novel indicator framework, elucidating previously neglected relationships between management practices, ecological functions, and provisioning of nutrients in harvested crops. We then applied this indicator framework to a case study in a remote region of Guatemala to test its ability to identify (1) synergies and tradeoffs between ecological and nutritional functions in a smallholder context, and (2) farmer capacities and management practices that shape agroecosystem resilience in the region.

\section{Agroecosystem Functioning, Adaptive Capacity, and Resilience in Eastern Guatemala}

Overall, our analysis of smallholder farms in eastern Guatemala illustrates a suite of synergistic and tradeoff dynamics between ecological and nutritional functions and resilience at the agroecosystem level. We tested three indicator pairs, Productivity, Quality, and Functional Diversity, in the case study, which revealed two synergistic (Quality, Functional Diversity) and one tradeoff (Productivity) relationship within a context of community and household-level shocks. Overall, six of the 15 unique combinations of indicators were significantly positively related, and two had significant tradeoffs. Positive relationships between indicators indicated that farmers tended to use multiple ecological practices simultaneously, or not at all, and that ecological and nutritional outcomes tended to be synergistic (either both negative or both positive). Results from our regression analysis of ecological and nutritional functional diversity (Functional Diversity indicators in the framework) further supported the positive relationship between ecological and nutritional functions and resilience of agroecosystems using continuous data.

In some cases, there were tradeoffs between ecological and nutritional indicators in the Guatemalan case, particularly between maize yield over time (1E; a Productivity indicator) and both staple food availability (1N) and multi-cropping (3E; a Quality indicator). We interpreted these tradeoffs as illustrations of farmers' coping capacity when facing environmental degradation and loss of land. Farmers were likely increasing their use of multi-cropping and relying on markets to purchase food in the near-term, enabling 


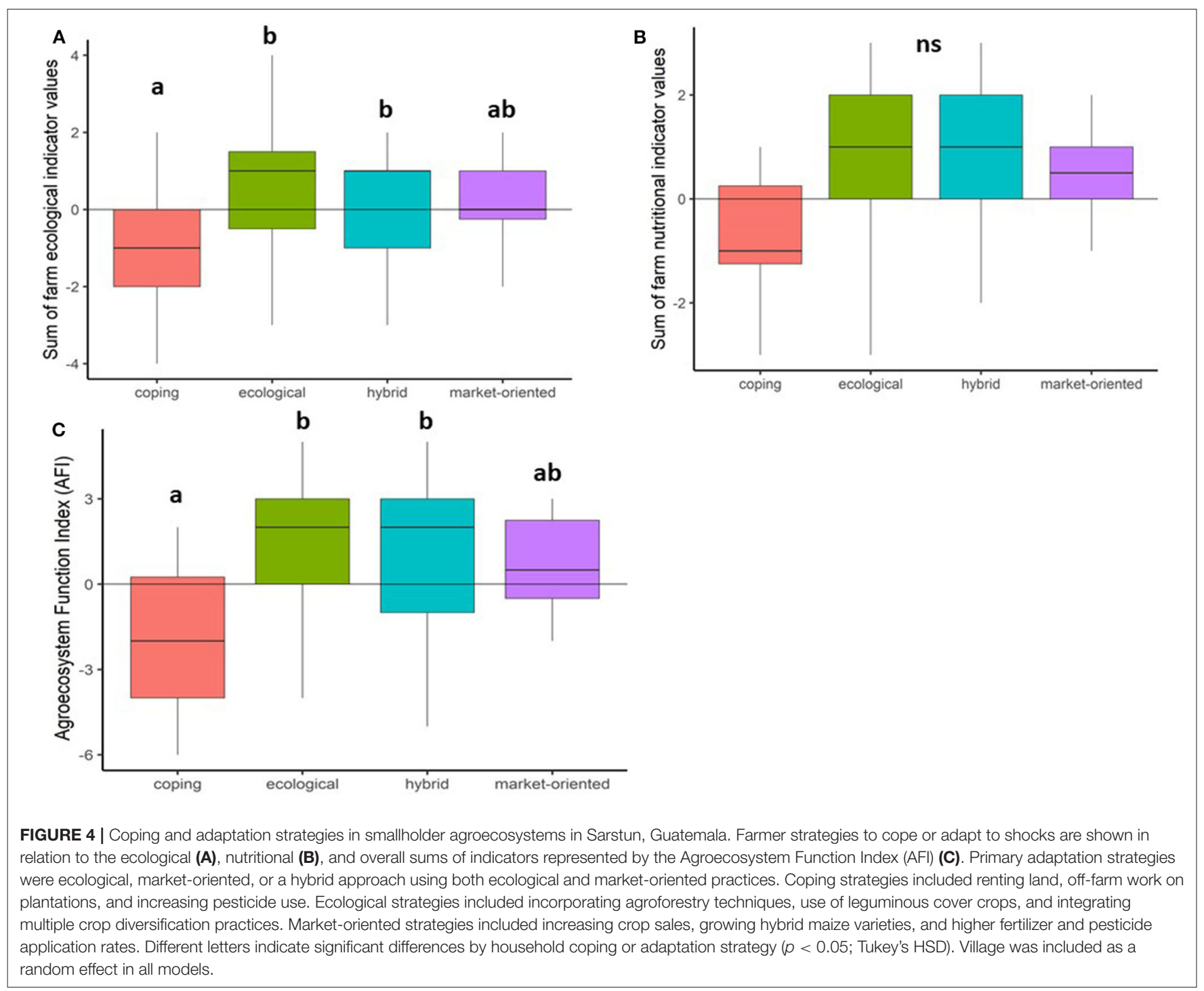

positive nutritional indicators even as ecological indicators were negative.

These tradeoffs may have resulted from temporal disparities, with nutritional indicators responding to change on short timescales and ecological indicators operating over longer timescales. For instance, renting agricultural land is a common practice in Sarstún (32\% of our sample), particularly on farms that have lost land through the community-level shock of land grabbing. Renting enables farmers to access relatively high-yielding land on a seasonal basis to produce a staple crop for family consumption, rather than working to improve degraded land with agroecological management for longterm food production. This practice decouples ecological and nutritional functions beyond a single growing season. As has been observed in other contexts, farmers in the sample openly commented that they chose not to use any fertilization methods, such as cover cropping, on rented lands, even if they actively incorporated them into fertility management on communally or privately-owned land in their possession (e.g., Fraser, 2004). Renting has the potential to underwrite extensive degradation of natural resources at the landscape level. Thus, even with rented land, Sarstún smallholders our sample still had mean maize yields that were five times lower than the Guatemalan national average.

Using ecological and nutritional indicators for resilience to community-level and idiosyncratic shocks, we identified the most adaptive and most vulnerable households across the sample. We found that farmers using ecological or hybrid (ecological and market-oriented) adaptation strategies had significantly higher levels of agroecosystem functioning (AFI) than farmers who were coping with losses of land by working on or renting from plantations (Figure 4, Table 5). Farmers relying on coping capacities such as renting or off-farm work were both ecologically and nutritionally more vulnerable than farmers using adaptive management practices such as cover cropping, agroforestry, or increased production of cash crops in a hybrid approach (Figure 4). Purely market-oriented farmers who did 
not integrate ecological practices had similarly low levels of agroecosystem functioning as coping farmers. Results from the interviews showcased farmers' capacity to adapt to shocks by using ecological and market-oriented strategies to promote agroecosystem functioning and resilience in the face of landscape degradation, land grabs, and climate change. While we found no evidence of transformative capacity in the Guatemalan case study (Béné et al., 2012), the indicator framework and index developed here could also be used to identify cases in which management practices are transformative.

\section{Agroecosystem Functioning, Adaptive Capacity, and Resilience in Other Contexts}

Previous work has identified similar synergies and tradeoffs between ecological and nutritional functions of smallholder agroecosystems, with marked impacts for adaptive capacity and resilience. One study in Northern Potosi, Bolivia, found that cropping system intensification on sloping mountain rangelands increased soil erosion and reduced soil organic matter, ultimately undermining productivity, food security, and farmer livelihoods (Vanek and Drinkwater, 2013). However, adapting management to apply phosphorus fertilization in concert with mixed legume-grass cover crops increased soil cover, biological nitrogen fixation, and nutrient availability and assimilation, with feedbacks that reduced erosion and increased crop productivity. Upon surpassing a soil fertility threshold through agroecological management, ecological and nutritional tradeoffs can become synergies that result in long-term positive states (also see Bennett et al., 2009, for related discussion using an ecosystem services framework).

The indicator framework presented in this paper could be applied in a wide range of contexts through the use of casespecific metrics for each indicator. The metrics in our case study were selected based on themes that farmers and key stakeholders identified in interviews, including agroecosystem functions affected by landscape degradation, loss of land tenure, and related livelihood changes. We defined ranges of values and thresholds to either match an established mean value and range (e.g., maize protein concentration from the FAO) or a relative range based on the distribution of values in the case study (e.g., nutritional functional diversity). Because the framework is designed to understand agroecosystem functioning and resilience to shocks in a particular context, this relative valuation approach is appropriate, as it enables comparison across farms and identification of the most vulnerable farms for targeted interventions.

Metrics for agroecosystems in less data-scarce regions could be developed to more closely represent the mechanistic links between specific ecological processes and their nutritional outcomes. For example, other possible pairs of metrics could include crop rotation complexity (2E) and diet diversity (measured for example, with Minimum Dietary Diversity for Women from the FAO) (FAO and FHI 360, 2016) (2N) for Diversity, which we were unable to capture in the Guatemalan case study. Community-level metrics relating farm management to broader ecological and nutritional outcomes could also be useful additions to the framework. Indicators may benefit from re-assignment or broader groupings depending on the context in which the framework is applied, as well as the levels of expected interaction between the specific variables selected for the indicators.

\section{Extending and Scaling the Framework: Structural Enablers and Constraints}

Social factors that shape farmer capacities for resilience, such as knowledge and skills, participation in social networks, and cultural and institutional influences, affect and interact with ecological and nutritional indicators at both agroecosystem and food system scales (Figure 1). Indirect relationships between this broader social context and indicators of agroecosystem function are not currently accounted for in our framework. Therefore, a first extension of this study could be to adopt a food systems resilience perspective and include socio-cultural determinants of adaptive capacity, human health, and food security and nutrition in the framework (Schipanski et al., 2016). Indicators could be sourced from existing frameworks (e.g., Cabell and Oelofse, 2012), which include complementary social indicators related to reflection and learning, and community-based, grassroots organization, among others. Integrating ecological and nutritional indicators with key sociocultural influences would be a logical next step to improve the indicators' ability to accurately represent the resilience of rural livelihoods (Chowdhury and Turner, 2006; Laney and Turner, 2015; Sterling et al., 2017).

Importantly, both environmental conditions and institutional structures can shape and constrain farmer capacities, resulting decision-making, and management systems, even when they lie outside of the agroecosystem's spatial boundary (Hendrickson and James, 2005; Currie, 2011; Brown, 2014). This is especially true in a Global South context, in which power imbalances and landscape-scale environmental degradation frequently go handin-hand (DeClerck et al., 2011). We found evidence in our case study, for example, that acute losses of land due to land grabbing at the community level were associated with significantly lower indicators of agroecosystem functioning relative to longerterm landscape-level shocks, including deforestation. At a higher level of social organization, dynamics of the agricultural governance system, particularly power-holding institutions such as governmental agricultural agencies, extension services, seed and chemical companies, and non-profit organizations shape and constrain the options available to small-scale producers (Stuart, 2009). Such organizations, as well as cultural norms, local knowledge and practices, and community expectations, influence smallholder resilience capacities (Scherr, 2000; Guerra et al., 2017). Because these power structures can determine land use and agricultural management practices, they impact ecological and nutritional functions, their interactions, and ultimately the resilience of agroecosystems.

Smallholders may also shift their ecological and nutritional outcomes by engaging with social networks and adaptive capacity at a community scale. Recent research has highlighted that community-level and regional crop diversity can often lead to stronger improvements in diet diversity and nutritional security 
than diversity at an agroecosystem level (Remans et al., 2015; Tobin et al., 2019). Complementing production diversity, access to markets (Jones, 2016; Koppmair et al., 2016) and the diversity of foods purchased at markets (Bellon et al., 2016) are key contributors to diet diversity and nutrition at a household level. Market-orientation, one form of adaptive capacity explored in our case study, can provide an additional pathway to diet quality through income generation for food purchases (Sibhatu et al., 2015a; Sibhatu and Qaim, 2018), although prior studies have noted that high-calorie, high shelf-life purchased foods that contribute to diet diversity may be supplanting more nutritious traditional foods even in rural contexts (Oyarzun et al., 2013). In remote settings (Koppmair et al., 2016) or the off-season for cash crop production (Some and Jones, 2018), however, the diversity of crops available on the farm gains relative importance. While our indicator framework does not explicitly include communityscale measures, we have demonstrated through our test case that it has potential to identify the effects of communitylevel shocks on households. By analyzing farmer marketorientation as a form of adaptive capacity, we were also able to examine the role of markets on agroecosystem functions and resilience, even the case study's remote context. As our findings demonstrate, however, market strategies do not necessarily increase smallholder resilience. Our findings aligned with prior work showing that market-orientation as an adaptation strategy shows potential to contribute to smallholder resilience but exposes smallholders to new risks that must be managed (Kuhl, 2018); we found that without a hybrid approach including ecological management strategies in addition to market-oriented strategies, resilient outcomes were not realized on farms. Given the growing literature on agrobiodiversity, diet diversity, and nutrition at larger scales, future work could extend our results by using the framework to study ecological and nutritional indicators at the community or regional scale. Similarly, a fifth indicator representing the social determinants of food security and nutrition, such market access or diversity, could be added to increase the framework's robustness and applicability in less remote regions.

Relatedly, including multiple sources and types of data (e.g., spatial, biophysical, and survey-based) could also improve the predictive ability of the indicator framework (e.g., Geoghegan et al., 2001). Due to Sarstún's remoteness, there is little up-todate agricultural and demographic data available, and so our case study relied primarily on observational data. Lack of data is a common issue in research on smallholder agriculture, and our framework offers a tool to analyze agroecosystem functioning and its relationship to adaptive capacity and resilience in datascarce contexts. By scaling indicator values to the maximum in a sample of smallholders, our relative approach to indicator quantification enables researchers and practitioners to identify the most adaptive and most vulnerable households. This approach could be used to target development resources to the households most in need following shocks that can precipitate both ecological degradation and food insecurity, such as land grabs (Alonso-Fradejas, 2012; D’Odorico et al., 2017). Similarly, the framework could also allow the identification of positive farm management strategies worth scaling up. Future frameworks developed for locations where fine-scale data is more freely available would benefit from empirical tests to better understand and incorporate the role of institutional and landscapelevel factors on agroecosystem-level social, ecological, and nutritional processes. Interactions between landscape context (e.g., Smith et al., 2020), governance, and farm management decisions affect the livelihoods and resilience of millions of smallholders.

\section{Feedbacks, Transitions, and Transformation in Agroecosystems}

The body of work on adaptation and resilience emphasizes the capacity of social-ecological systems to not just maintain stability in the face of shocks but also to adapt or transformdefined as a shift to novel system states or components-as their context changes (Walker et al., 2004; Cote and Nightingale, 2012). In smallholder agroecosystems, social-ecological resilience offers a framework to critically examine not only ecological and nutritional functions, but also their interactions and feedbacks over time (Darnhofer et al., 2010; Béné et al., 2016). Feedbacks can be adaptive or maladaptive. These feedbacks contribute to system functions and act as drivers of agricultural transformations, affecting ecosystem stability and human health.

Our analysis, which combined quantitative and qualitative methods, focused on interactions between ecological, and nutritional functions and their relationships to the adaptive capacity of smallholder agroecosystems. In this framing, tradeoffs and negative feedbacks can lead to ecological degradation and human malnourishment over time, whereas synergies and positive feedbacks result in ecological sustainability and human nutrition (Figure 1). There was strong evidence of both coping and adaptive capacities among smallholders in our case study. Data suggest that managing for short-term nutritional functions (e.g., by renting land for a single growing season to produce higher yields; coping) over longer-term ecological functions (e.g., through agroecological management of landholdings; ecological adaptation) could result in negative trajectories for both environmental and human well-being over time.

Adaptive or transformative management at the farm-scale may contribute to agroecosystem resilience by reinforcing ecological and nutritional functions, creating adaptive feedbacks that lead to greater system resilience (Jones et al., 2013; Vanek et al., 2016) (Figure 1). Alternatively, management may set off a chain reaction of destabilizing ecological and nutritional functions that lead to agroecosystem degradation via maladaptive feedbacks (Scherr, 2000; Birge et al., 2016). Each of these cycles could result in agroecosystem transformation. However, the former adaptive feedback model would work to the advantage of smallholder households through ecosystem regeneration and sustainable diets (Allen et al., 2014), whereas the latter could result in an unsustainable system, and, over time, household or community-scale malnutrition (Bezner-Kerr et al., 2010; Snapp et al., 2010; Schipanski et al., 2016). If agricultural products are sold or traded, these feedbacks could broadcast beyond the level of the agroecosystem to affect communities or the wider region. 
In response to landscape degradation, smallholder farmers often adopt coping strategies that allow their households to maintain their nutritional provisioning despite widespread erosion of the natural resource base. However, these same strategies may prevent deliberate and positive long-term resilience or transformation of the agroecosystem (O'Brien, 2012; Béné et al., 2016). With reduced ecological functioning at the landscape level, agroecosystem transformation is likely to occur regardless of temporary coping behaviors to bolster household food security (Kates et al., 2012; O’Brien, 2012). In the case study, this could include farmer emigration to Guatemala City, or families transitioning out of agriculture to work in coastal fisheries or the nascent ecotourism industry (e.g., Katz, 2015); alternatively, it could include farm transitions to agroecological management. Notably, the quality of this transformation will look very different depending on whether additional households adopt ecological management strategies-such as those on 53\% of farms in our studythat demonstrate adaptive capacity and contribute to resilience in spite of the impaired environmental status of the overall landscape. Observed tradeoffs, such as between the ecological and nutritional indicators representing Productivity in the case study, suggest the need for targeted policies or interventions to support longer-term synergies between ecological and nutritional functions of smallholder agroecosystems (Béné et al., 2016).

A temporal extension of our framework could parse out these short- and long-term dynamics of agroecosystem resilience. Future quantitative analyses could discern changes over time, causality, and interactions between indicators using continuous metrics and time series data, uncovering feedbacks and potential pathways to system transformation. Expanding the indicator framework to account for temporal dynamics and transformation could improve its predictive ability and utility for agroecosystem management over longer time-scales or under changing environmental conditions. Additional analyses of ways that farmers' wellbeing and nutrition, in turn, influences their capacity to engage in adaptive management would also be of interest, particularly related to practices that are labor-intensive or physically demanding.

\section{CONCLUSIONS}

With escalating human and environmental pressure on global agricultural landscapes, adaptive capacity is an increasingly essential tool for smallholder farmers to maintain agroecosystem functioning, and through it, their livelihoods. We created a novel indicator framework to demonstrate the importance of linking ecological and nutritional functions of agroecosystems to leverage their synergies. Using a case study of smallholder farms in a remote region of eastern Guatemala, we found that adaptive management practices tended to produce synergistic ecological and nutritional relationships, whereas coping and market-oriented strategies prioritized basic nutritional functions while undermining ecological ones. Practices that leveraged ecological and nutritional synergies to improve agroecosystem functioning demonstrated smallholders' capacity for resilience in degraded environments.

To foster resilient agroecosystems, we must meet the dual goals of bolstering ecological functions while producing sufficient quantities of high-quality food to ensure food security and nutrition for all people. Our framework establishes that these two goals can be synergistic in smallholder agroecosystems and that farmers can adopt management strategies in line with both ecological and nutritional goals. This adaptable indicator framework can help identify best practices that lead to ecological and nutritional synergies in diverse agroecosystems and contexts and could support decision-makers in targeting supportive resources to the most vulnerable households. The ecological and nutritional indicators proposed here enable nuanced analyses of adaptive capacity and resilience in data-scarce agricultural regions. Future work could relate ecological and nutritional indicators at larger spatial and temporal scales to incorporate the community, landscape, and governance conditions that enable farmers to manage agroecosystems for resilience.

\section{DATA AVAILABILITY STATEMENT}

The raw data supporting the conclusions of this article will be made available by the authors, without undue reservation.

\section{ETHICS STATEMENT}

The studies involving human participants were reviewed and approved by Tufts University Social, Behavioral, and Educational Research Institutional Review Board and determined to be of exempt status: IRB study \# 1403034. Written informed consent for participation was not required for this study in accordance with the national legislation and the institutional requirements.

\section{AUTHOR CONTRIBUTIONS}

AES designed the study, conducted case study fieldwork and lab work, and led data analysis, with support from LK. AES, JB, and LK constructed the indicator framework and envisioned the paper. AES wrote the manuscript, with substantial contributions from JB and LK. All authors contributed to the article and approved the submitted version.

\section{FUNDING}

This study was supported by the Tufts University Summer Scholars Program, the School for Environment and Sustainability at the University of Michigan, and the National Science Foundation Graduate Research Fellowship Program (No. 1841052).

\section{ACKNOWLEDGMENTS}

The authors would like to thank the current and former staff of EcoLogic Development Fund and APROSARSTUN for 
providing invaluable guidance and on-the-ground support for the Guatemalan case study, as well as the many Q'eqchi' and Ladino farmer participants for their time and input. We thank Drs. Colin Orians and Alex Blanchette at Tufts University for their helpful comments on an early draft of this manuscript, as well as Beth VanDusen, Alison Bressler, Etienne Herrick, Eliot Jackson, and other members of the Blesh Agroecology Lab at the University of Michigan for feedback on later drafts. Thanks to Tim G. Williams for support with data analysis and

\section{REFERENCES}

Adger, W. N. (2000). Social and ecological resilience: are they related? Prog. Hum. Geogr. 24, 347-364. doi: 10.1191/030913200701540465

Ahmed, S., and Stepp, J. R. (2016). Beyond yields: climate change effects on specialty crop quality and agroecological management. Elem. Sci. Anthr. 4, 1-16. doi: 10.12952/journal.elementa.000092

Allen, T., Prosperi, P., Cogill, B., and Flichman, G. (2014). Agricultural biodiversity, social-ecological systems and sustainable diets. Proc. Nutr. Soc. 73, 498-508. doi: 10.1017/S002966511400069X

Alonso-Fradejas, A. (2012). Land control-grabbing in guatemala: the political economy of contemporary agrarian change. Can. J. Dev. Stud. 33, 509-528. doi: 10.1080/02255189.2012.743455

Altieri, M. A. (1999). The ecological role of biodiversity in agroecosystems. Agric. Ecosyst. Environ. 74, 19-31. doi: 10.1016/S0167-8809(99)00028-6

Altieri, M. A., Nicholls, C. I., Henao, A., and Lana, M. A. (2015). Agroecology and the design of climate change-resilient farming systems. Agron. Sustain. Dev. 35, 869-890. doi: 10.1007/s13593-015-0285-2

Bailey, I., and Buck, L. E. (2016). Managing for resilience: a landscape framework for food and livelihood security and ecosystem services. Food Secur. 8, 477-490. doi: 10.1007/s12571-016-0575-9

Bellon, M. R., Ntandou-Bouzitou, G. D., and Caracciolo, F. (2016). On-farm diversity and market participation are positively associated with dietary diversity of rural mothers in southern Benin, West Africa. PLoS ONE 11:e0162535. doi: 10.1371/journal.pone.0162535

Béné, C., Headey, D., Haddad, L., and Grebmer, K., Von (2016). Is resilience a useful concept in the context of food security and nutrition programmes? Some conceptual and practical considerations. Food Secur. 8, 123-138. doi: 10.1007/s12571-015-0526-x

Béné, C., Prager, S. D., Achicanoy, H. A. E., Toro, P. A., Lamotte, L., Bonilla, C., et al. (2019). Global map and indicators of food system sustainability. Sci. Data 6, 1-15. doi: 10.1038/s41597-019-0301-5

Béné, C., Wood, R. G., Newsham, A., and Davies, M. (2012). Resilience: new utopia or new tyranny? Reflection about the potentials and limits of the concept of resilience in relation to vulnerability reduction programmes. Br. Ecol. Soc. 2012, 1-61. doi: 10.1111/j.2040-0209.2012.00405.x

Bennett, E. M., Peterson, G. D., and Gordon, L. J. (2009). Understanding relationships among multiple ecosystem services. Ecol. Lett. 12, 1394-1404. doi: 10.1111/j.1461-0248.2009.01387.x

Berdegué, J. A., and Fuentealba, R. (2011). “The state of smallholders in agriculture in Latin America," in Conference on New Directions for Smallholder Agriculture (Rome), 1-37.

Berkes, F., and Ross, H. (2013). Community resilience: toward an integrated approach. Soc. Nat. Resour. 26, 5-20. doi: 10.1080/08941920.2012.736605

Bezner-Kerr, R., Berti, P. R., and Shumba, L. (2010). Effects of a participatory agriculture and nutrition education project on child growth in northern Malawi. Public Health Nutr. 14, 1466-1472. doi: 10.1017/S1368980010002545

Birge, H., Bevans, R. A., Allen, C. R., Angeler, D. G., Baer, S. G., and Wall, D. H. (2016). Adaptive management for soil ecosystem services. J. Environ. Manage. 183, 371-378. doi: 10.1016/j.jenvman.2016.06.024

Black, R. E., Allen, L. H., Bhutta, Z. A., Caulfield, L. E., de Onis, M., Ezzati, M., et al. (2008). Maternal and child undernutrition: global and regional exposures and health consequences. Lancet 371, 243-260. doi: 10.1016/S0140-6736(07)61690-0 figures. Finally, we would also like to thank our two reviewers, each of whom provided constructive feedback that substantially improved the manuscript.

\section{SUPPLEMENTARY MATERIAL}

The Supplementary Material for this article can be found online at: https://www.frontiersin.org/articles/10.3389/fsufs. 2020.543914/full\#supplementary-material

Blesh, J. (2018). Functional traits in cover crop mixtures: Biological nitrogen fixation and multifunctionality. J. Appl. Ecol. 55, 38-48. doi: 10.1111/1365-2664.13011

Blesh, J. (2019). Feedbacks between nitrogen fixation and soil organic matter increase ecosystem functions in diversified agroecosystems. Ecol. Appl. 29, 1-12. doi: 10.1002/eap.1986

Blesh, J., and Wittman, H. (2015). "Brasilience:” Assessing resilience in land reform settlements in the brazilian cerrado. Hum. Ecol. 43, 531-546. doi: 10.1007/s10745-015-9770-0

Botta-Dukat, Z. (2005). Rao's quadratic entropy as a measure of functional diversity based on multiple traits. J. Veg. Sci. 16, 533-540. doi: 10.1111/j.1654-1103.2005.tb02393.x

Brandt, K., Leifert, C., Sanderson, R., and Seal, C. J. (2011). Agroecosystem management and nutritional quality of plant foods: the case of organic fruits and vegetables. CRC. Crit. Rev. Plant Sci. 30, 177-197. doi: 10.1080/07352689.2011.554417

Bressani, R., and Scrimshaw, S. (1958). Effect of lime treatment on in vitro availability of essential amino acids and solubility of protein fractions in corn. Agric. Food Chem. 179, 774-778. doi: 10.1021/jf60092a010

Brooker, R. W., Bennett, A. E., Cong, W., Daniell, T. J., George, T. S., Hallett, P. D., et al. (2015). Improving intercropping: a synthesis of research in agronomy, plant physiology and ecology. New Phytol. 206, 107-117. doi: $10.1111 /$ nph.13132

Brooker, R. W., Karley, A. J., Newton, A. C., Pakeman, R. J., and Schöb, C. (2016). Facilitation and sustainable agriculture: a mechanistic approach to reconciling crop production and conservation. Funct. Ecol. 30, 98-107. doi: 10.1111/1365-2435.12496

Brown, K. (2014). Global environmental change I: a social turn for resilience? Prog. Hum. Geogr. 38, 107-117. doi: 10.1177/0309132513498837

Büchs, W. (2003). Biodiversity and agri-environmental indicators - general scopes and skills with special reference to the habitat level. Agric. Ecosyst. Environ. 98, 35-78. doi: 10.1016/S0167-8809(03)00070-7

Bygbjerg, I. C. (2012). Double burden of noncommunicable and infectious diseases in developing countries. Science 337, 1499-1502. doi: 10.1126/science.1223466

Cabell, J. F., and Oelofse, M. (2012). An indicator framework for assessing agroecosystem resilience. Ecol. Soc. 17:18. doi: 10.5751/ES-04666-170118

Callo-Concha, D., and Ewert, F. (2014). Using the concepts of resilience, vulnerability and adaptability for the assessment and analysis of agricultural systems. Chang. Adapt. Socio Ecol. Syst. 1, 1-11. doi: 10.2478/cass2014-0001

Carpenter, S., Walker, B., Anderies, J. M., and Abel, N. (2001). From metaphor to measurement: resilience of what to what? Ecosystems 4, 765-781. doi: 10.1007/s10021-001-0045-9

Casanoves, F., Pla, L., Di Rienzo, J. A., and Díaz, S. (2011). FDiversity: a software package for the integrated analysis of functional diversity. Methods Ecol. Evol. 2, 233-237. doi: 10.1111/j.2041-210X.2010.00082.x

Cassidy, E. S., West, P. C., Gerber, J. S., and Foley, J. A. (2013). Redefining agricultural yields: from tonnes to people nourished per hectare. Environ. Res. Lett. 8:034015. doi: 10.1088/1748-9326/8/3/ 034015

Chowdhury, R. R., and Turner, B. L. (2006). Reconciling agency and structure in empirical analysis: Smallholder land use in the Southern Yucatán, Mexico. Ann. Assoc. Am. Geogr. 96, 302-322. doi: 10.1111/j.1467-8306.2006.00479.x 
Coadministración, C. (2009). La Conservación de los Recursos Naturales y el Desarrollo Integral de Los Pueblos Indígenas del Área Protegida -Área de Uso Múltiple Río Sarstún. Guatemala City: Plan Maestro 2010-2014 Área de Uso Múltiple Río Sarstún.

Cohn, A. S., Newton, P., Gil, J. D. B., Kuhl, L., Samberg, L., Ricciardi, V., et al. (2017). Smallholder agriculture and climate change. Annu. Rev. Environ. Resour. 42, 347-375. doi: 10.1146/annurev-environ-102016-060946

Cote, M., and Nightingale, A. J. (2012). Resilience thinking meets social theory: Situating social change in socio-ecological systems (SES) research. Prog. Hum. Geogr. 36, 475-489. doi: 10.1177/0309132511425708

Currie, W. S. (2011). Units of nature or processes across scales? The ecosystem concept at age 75. New Phytol. 190, 21-34. doi: 10.1111/j.1469-8137.2011.03646.x

Dainese, M., Martin, E. A., Aizen, M. A., Albrecht, M., Bommarco, R., Carvalheiro, L. G., et al. (2019). A global synthesis reveals biodiversitymediated benefits for crop production. Res. Prog. Water Land Ecosyst. 5, 1-19. doi: 10.1126/sciadv.aax0121

Darnhofer, I., Fairweather, J., and Moller, H. (2010). Assessing a farm's sustainability: insights from resilience thinking. Int. J. Agric. Sustain. 8, 186-198. doi: 10.3763/ijas.2010.0480

DeClerck, F. A. J., Fanzo, J., Palm, C., and Remans, R. (2011). Ecological approaches to human nutrition. Food Nutr. Bull. 32, S41-S50. doi: $10.1177 / 15648265110321$ S106

D’Odorico, P., Rulli, M. C., Dell'Angelo, J., and Davis, K. F. (2017). New frontiers of land and water commodification: socio-environmental controversies of largescale land acquisitions. Land Degrad. Dev. 28, 2234-2244. doi: 10.1002/ldr.2750

Drinkwater, L. E., Schipanski, M. E., Snapp, S. S., and Jackson, L. E. (2008). "Ecologically based nutrient management," in Agricultural Systems: Agroecology and Rural Innovation for Development, eds S. Snapp and B. Pound (London: Academic Press, Inc.), 159-207.

Elmqvist, T., Folke, C., Nyström, M., Peterson, G., Bengtsson, J., Walker, B., et al. (2003). Response diversity, ecosystem change, and resilience. Front. Ecol. Environ. 1:488. doi: 10.1890/1540-9295(2003)001[0488:RDECAR]2.0.CO;2

FAO (2008). "An Introduction to the Basic Concepts of Food Security," in Food Security Information for Action: Practical Guides (Rome: Food and Agriculture Organization of the United Nations), 1-3.

FAO and FHI 360 (2016). Minimum Dietary Diversity for Women: A Guide to Measurement. Rome: Food and Agriculture Organization of the United Nations.

Finney, D. M., and Kaye, J. P. (2016). Functional diversity in cover crop polycultures increases multifunctionality of an agricultural system. J. Appl. Ecol. 54, 509-517. doi: 10.1111/1365-2664.12765

Folke, C. (2006). Resilience: The emergence of a perspective for socialecological systems analyses. Glob. Environ. Chang. 16, 253-267. doi: 10.1016/. gloenvcha.2006.04.002

Fraser, E. D. (2004). Land tenure and agricultural management: soil conservation on rented and owned fields in southwest British Columbia. Agric. Hum. Values 21, 73-79. doi: 10.1023/B:AHUM.0000014020. 96820.a1

Fuentes Lopez, M. R. (2005). Maiz para Guatemala: Propuesta Para la Reactivacion de la Cadena Agroalimentaria del Maiz Blanco Y Amarillo. Guatemala: Organización de las Naciones Unidas para la Agricultura y Alimentación.

Galicia, L., Nurit, E., Rosales, A., and Palacios-Rojas, N. (2009). Maize Nutrition Quality and Plant Tissue Analysis Laboratory. Mexico: CIMMYT. Available online at: http://scholar.google.com/scholar?hl=en\&btnG=Search\&q=intitle: Maize+nutrition+quality+and+plant+tissue+analysis+laboratory\#2 (accessed March 16, 2020).

Garibaldi, L. A., Steffan-Dewenter, I., Winfree, R., Aizen, M. A., Bommarco, R., Cunningham, S. A., et al. (2013). Wild pollinators enhance fruit set of crops regardless of honey bee abundance. Science 339, 1608-1611. doi: $10.1126 /$ science. 1230200

Geoghegan, J., Villar, S. C., Klepeis, P., Mendoza, P. M. A., Ogneva-Himmelberger, Y., Chowdhury, R. R., et al. (2001). Modeling tropical deforestation in the southern Yucatán peninsular region: Comparing survey and satellite data. Agric. Ecosyst. Environ. 85, 25-46. doi: 10.1016/S0167-8809(01)00201-8

Grandia, L. (2012). Enclosed: Conservation, Cattle, and Commerce Among the Q'eqchi' Maya Lowlanders. Seattle: University of Washington Press.
Guerra, J., Blesh, J., Schmitt Filho, A. L., and Wittman, H. (2017). Pathways to agroecological management through mediated markets in Santa Catarina, Brazil. Elem. Sci. Anthr. 5:67. doi: 10.1525/elementa.248

Gunaratna, N. S., Groote, H., De Nestel, P., Pixley, K. V., and McCabe, G. P. (2010). A meta-analysis of community-based studies on quality protein maize. Food Policy 35, 202-210. doi: 10.1016/j.foodpol.2009.11.003

Hendrickson, M. K., and James, H. S. (2005). The ethics of constrained choice: how the industrialization of agriculture impacts farming and farmer behavior. J. Agric. Environ. Ethics 18, 269-291. doi: 10.1007/s10806-0050631-5

Herrero, M., Thornton, P. K., Power, B., Bogard, J. R., Remans, R., Fritz, S., et al. (2017). Farming and the geography of nutrient production for human use: a transdisciplinary analysis. Lancet Planet. Heal. 1, e33-e42. doi: 10.1016/S2542-5196(17)30007-4

Hinsinger, P., Betencourt, E., Bernard, L., Brauman, A., Plassard, C., Shen, J., et al. (2011). P for Two, sharing a scarce resource: soil phosphorus acquisition in the rhizosphere of intercropped species. Plant Physiol. 156, 1078-1086. doi: 10.1104/pp.111.175331

Holling, C. S. (1973). Resilience and stability of ecological systems. Annu. Rev. Ecol. Syst. 4, 1-23. doi: 10.1146/annurev.es.04.110173.000245

Hunter, M. D. (2016b). "Chapter 3: The Variable Chemistry of Primary Production," in The Phytochemical Landscape (Princeton, NJ: Princeton University Press), 24-38.

Hunter, M. D. (2016a). "Chapter 2: The Phytochemical Landscape," in The Phytochemical Landscape (Princeton, NJ: Princeton University Press), 13-23. doi: 10.1515/9781400881208-003

Instituto Nacional de Estadística (2013). Caracterización estadística República de Guatemala 2012. Inst. Nac. Estadística, 76. Available online at: http://www.ine.gob.gt/sistema/uploads/2014/02/26/ 5eTCcFlHErnaNVeUmm3iabXHaKgXtw0C.pdf (accessed March 16, 2020).

Isakson, S. R. (2009). No hay ganancia en la milpa: the agrarian question, food sovereignty, and the on-farm conservation of agrobiodiversity in the guatemalan highlands. J. Peasant Stud. 36, 725-759. doi: 10.1080/03066150903353876

Jacobi, J., Mukhovi, S., Llanque, A., Augstburger, H., Käser, F., Pozo, C., et al. (2018). Operationalizing food system resilience: An indicator-based assessment in agroindustrial, smallholder farming, and agroecological contexts in Bolivia and Kenya. Land Use Policy 79, 433-446. doi: 10.1016/j.landusepol.2018. 08.044

Jones, A. D. (2016). On-farm crop species richness is associated with household diet diversity and quality in subsistence- and market-oriented farming households in Malawi. J. Nutr. 147, 86-96. doi: 10.3945/jn.116.235879

Jones, A. D. (2017). Critical review of the emerging research evidence on agricultural biodiversity, diet diversity, and nutritional status in low- and middle-income countries. Nutr. Rev. 75, 769-782. doi: 10.1093/nutrit/ nux040

Jones, A. D., Hoey, L., Blesh, J., Miller, L., Green, A., and Shapiro, L. F. (2016). A Systematic review of the measurement of sustainable diets. Adv. Nutr. 7, 641-664. doi: 10.3945/an.115.011015

Jones, D. L., Cross, P., Withers, P. J. A., DeLuca, T. H., Robinson, D. A., Quilliam, R. S., et al. (2013). Nutrient stripping: the global disparity between food security and soil nutrient stocks. J. Appl. Ecol. 50, 851-862. doi: 10.1111/1365-2664.12089

Kates, R. W., Travis, W. R., and Wilbanks, T. J. (2012). Transformational adaptation when incremental adaptations to climate change are insufficient. Proc. Natl. Acad. Sci. U.S.A. 109, 7156-7161. doi: 10.1073/pnas.1115 521109

Katz, N. (2015). An Eco-Tour of Guatemala's Rio Dulce Region. New York, NY: New York Times.

Koppmair, S., Kassie, M., and Qaim, M. (2016). Farm production, market access and dietary diversity in Malawi. Public Health Nutr. 20, 325-335. doi: $10.1017 /$ S1368980016002135

Kremen, C., and Merenlender, A. M. (2018). Landscapes that work for biodiversity and people. Science 362, 1-9. doi: 10.1126/science.aau6020

Kremen, C., and Miles, A. (2012). Ecosystem services in biologically diversified versus conventional farming systems: benefits, externalitites, and trade-offs. Ecol. Soc. 17, 1-23. doi: 10.5751/ES-05035-170440 
Kuhl, L. (2018). Potential contributions of market-systems development initiatives for building climate resilience. World Dev. 108, 131-144. doi: 10.1016/j.worlddev.2018.02.036

Lal, R. (2009). Soil degradation as a reason for inadequate human nutrition. Food Secur. 1, 45-57. doi: 10.1007/s12571-009-0009-z

Laney, R., and Turner, B. L. (2015). The persistence of self-provisioning among smallholder farmers in northeast Madagascar. Hum. Ecol. 43, 811-826. doi: 10.1007/s10745-015-9791-8

Letourneau, D. K., Armbrecht, I., Salguero Rivera, B., Montoya Lerma, J., Jimenez Carmona, E., Constanza Daza, M., et al. (2011). Does plant diversity benefit agroecosystems? A synthetic review. Ecol. Appl. 21, 9-21. doi: 10.1890/09-2026.1

Li, B., Li, Y., Wu, H., Zhang, F., Li, C., Li, X., et al. (2016). Root exudates drive interspecific facilitation by enhancing nodulation and $\mathrm{N} 2$ fixation. Proc. Natl. Acad. Sci. U.S.A. 113, 6496-6501. doi: 10.1073/pnas.1523580113

Liu, J., Dietz, T., Carpenter, S. R., Alberti, M., Folke, C., Moran, E., et al. (2007). Complexity of coupled human and natural systems. Science 317, 1513-1516. doi: $10.1126 /$ science. 1144004

Liu, R. H. (2003). Health benefits of fruit and vegetables are from additive and synergistic combinations of phytochemicals. Am. J. Clin. Nutr. 78(Suppl. 3), 517S-520S. doi: 10.1093/ajcn/78.3.517S

Luckett, B. G., Declerck, F. A. J., Fanzo, J., Mundorf, A. R., and Rose, D. (2015). Application of the nutrition functional diversity indicator to assess food system contributions to dietary diversity and sustainable diets of Malawian households. Public Health Nutr. 18:2479-2487. doi: 10.1017/S136898001500169X

Martin, A. R., and Isaac, M. E. (2015). Plant functional traits in agroecosystems: a blueprint for research. J. Appl. Ecol. 52, 1425-1435. doi: 10.1111/1365-2664.12526

Matson, P. A., Parton, W. J., Power, A. G., and Swift, M. J. (1997). Agricultural intensification and ecosystem properties. Science. 277, 504-509. doi: $10.1126 /$ science.277.5325.504

McIntyre, B. D., Herren, H. R., Wakhungu, J., and Watson, R. T. (2009). "Agriculture at a crossroads: global report," in International Assessment of Agricultural Knowledge, Science and Technology for Development (IAASTD) (Washington, DC: Island Press).

Moonen, A. C., and Bàrberi, P. (2008). Functional biodiversity: an agroecosystem approach. Agric. Ecosyst. Environ. 127, 7-21. doi: 10.1016/j.agee.2008.02.013

Nelson, E., Mendoza, G., Regetz, J., Polasky, S., Tallis, H., Cameron, D. R., et al. (2009). Modeling multiple ecosystem services, biodiversity conservation, commodity production, and tradeoffs at landscape scales. Front. Ecol. Environ. 7, 4-11. doi: $10.1890 / 080023$

O'Brien, K. (2012). Global environmental change II: From adaptation to deliberate transformation. Prog. Hum. Geogr. 36, 667-676. doi: 10.1177/0309132511425767

Oyarzun, P. J., Borja, R. M., Sherwood, S., and Parra, V. (2013). Making sense of agrobiodiversity, diet, and intensification of smallholder family farming in the highland andes of ecuador. Ecol. Food Nutr. 52, 515-541. doi: 10.1080/03670244.2013.769099

Pelletier, B., Hickey, G., Bothi, K. L., and Mude, A. (2016). Linking rural livelihood resilience and food security: an international challenge. Food Secur. 8:576. doi: 10.1007/s12571-016-0576-8

Peterson, C. A., Eviner, V. T., and Gaudin, A. C. M. (2018). Ways forward for resilience research in agroecosystems. Agric. Syst. 162, 19-27. doi: 10.1016/j.agsy.2018.01.011

Pimm, S. L. (1984). The complexity and stability of ecosystems. Nature 307, 321-326. doi: 10.1038/307321a0

Power, A. G. (2010). Ecosystem services and agriculture: tradeoffs and synergies. Philos. Trans. R. Soc. B 365, 2959-2971. doi: 10.1098/rstb.2010.0143

Prosperi, P., Allen, T., Cogill, B., Padilla, M., and Peri, I. (2016). Towards metrics of sustainable food systems: a review of the resilience and vulnerability literature. Environ. Syst. Decis. 36, 3-19. doi: 10.1007/s10669-016-9584-7

Quinlan, A. E., Berbes-Blazquez, M., Haider, L. J., and Peterson, G. D. (2016). Measuring and assessing resilience: broadening understanding through multiple disciplinary perspectives. J. Appl. 53, 677-687. doi: $10.1111 / 1365-2664.12550$

R Core Team (2019). R: A Language and Environment for Statistical Computing. Vienna: R Found. Stat. Comput. Available online at: https://www.r-project.org/ (accessed March 16, 2020).
Raseduzzaman, M., and Jensen, E. S. (2017). Does intercropping enhance yield stability in arable crop production? A meta-analysis. Eur. J. Agron. 91, 25-33. doi: 10.1016/j.eja.2017.09.009

Remans, R., DeClerck, F. A. J., Kennedy, G., and Fanzo, J. (2015). Expanding the view on the production and dietary diversity link: scale, function, and change over time. Proc. Natl. Acad. Sci. U.S.A. 112, E6082. doi: $10.1073 /$ pnas. 1518531112

Remans, R., Fanzo, J., Palm, C. A., and Declerck, F. (2012). "Ecology and Human Nutrition," in Integrating Ecology and Poverty Reduction: Ecological Dimensions, ed. J. C. Ingram (New York, NY: Springer), 53-75. doi: 10.1007/978-1-4419-0633-5_4

Remans, R., Flynn, D. F. B., DeClerck, F., Diru, W., Fanzo, J., Gaynor, K., et al. (2011). Assessing nutritional diversity of cropping systems in african villages. PLoS ONE 6:e21235. doi: 10.1371/journal.pone.0021235

Ricciardi, V., Ramankutty, N., Mehrabi, Z., Jarvis, L., and Chookolingo, B. (2018). How much of the world's food do smallholders produce? Glob. Food Sec. 17, 64-72. doi: 10.1016/j.gfs.2018.05.002

Robertson, G. P., and Vitousek, P. M. (2009). Nitrogen in agriculture: balancing the cost of an essential resource. Annu. Rev. Environ. Resour. 34, 97-125. doi: 10.1146/annurev.environ.032108.105046

Rodriguez, J. P., Beard T. D. Jr., Bennett, E. M., Cumming, G. S., Cork, S., Agard, J., et al. (2006). Trade-offs across space, time, and ecosystem services. Ecol. Soc. 11:28. doi: 10.5751/ES-01667-110128

Scherr, S. J. (2000). A downward spiral? Research evidence on the relationship between poverty and natural resource degradation. Food Policy 25, 479-498. doi: 10.1016/S0306-9192(00)00022-1

Schipanski, M. E., MacDonald, G. K., Rosenzweig, S., Chappell, M. J., Bennett, E. M., Bezner Kerr, R., et al. (2016). Realizing resilient food systems. Bioscience 66, 600-610. doi: 10.1093/biosci/biw052

Schleuter, D., Daufresne, M., Massol, F., and Argillier, C. (2010). A user's guide to functional diversity indices. Ecol. Monogr. 80, 469-484. doi: 10.1890/08-2225.1

Shennan, C. (2008). Biotic interactions, ecological knowledge and agriculture. Philos. Trans. R. Soc. B 363, 717-739. doi: 10.1098/rstb.2007.2180

Sibhatu, K. T., Krishna, V. V., and Qaim, M. (2015a). Production diversity and dietary diversity in smallholder farm households. Proc. Natl. Acad. Sci. U.S.A. 112, 10657-10662. doi: 10.1073/pnas.1510982112

Sibhatu, K. T., Krishna, V. V., and Qaim, M. (2015b). Reply to Remans et al. Strengthening markets is key to promote sustainable agricultural and food systems. Proc. Natl. Acad. Sci. U.S.A. 112:E6083. doi: 10.1073/pnas.15190 45112

Sibhatu, K. T., and Qaim, M. (2018). Review: meta-analysis of the association between production diversity, diets, and nutrition in smallholder farm households. Food Policy 77, 1-18. doi: 10.1016/j.foodpol.2018.04.013

Smith, O. M., Cohen, A. L., Reganold, J. P., Jones, M. S., Orpet, R. J., Taylor, J. M., et al. (2020). Landscape context affects the sustainability of organic farming systems. Proc. Natl. Acad. Sci. U.S.A. 117, 2870-2878. doi: 10.1073/pnas.1906909117

Snapp, S. S., Blackie, M. J., Gilbert, R. A., Bezner-Kerr, R., and Kanyama-Phiri, G. Y. (2010). Biodiversity can support a greener revolution in Africa. Proc. Natl. Acad. Sci. U.S.A. 107, 20840-20845. doi: 10.1073/pnas.1007199107

Snapp, S. S., Swinton, S. M., Labarta, R., Mutch, D., Black, J. R., Leep, R., et al. (2005). Evaluating cover crops for benefits, costs and performance within cropping system niches. Agron. J. 97, 1-11. doi: 10.2134/agronj2005. 0322a

Some, J. W., and Jones, A. D. (2018). The influence of crop production and socioeconomic factors on seasonal household dietary diversity in Burkina Faso. PLoS ONE 13:e0195685. doi: 10.1371/journal.pone.0195685

Steffan-Dewenter, I., Kessler, M., Barkmann, J., Bos, M. M., Buchori, D., Erasmi, S., et al. (2007). Tradeoffs between income, biodiversity, and ecosystem functioning during tropical rainforest conversion and agroforestry intensification. Proc. Natl. Acad. Sci. U.S.A. 104, 4973-4978. doi: 10.1073/pnas.0608409104

Sterling, E., Ticktin, T., Kipa, T., Morgan, K., Cullman, G., Alvira, D., et al. (2017). Culturally grounded indicators of resilience in social-ecological systems. Environ. Soc. Adv. Res. 8, 63-95. doi: 10.3167/ares.2017.080104

Stuart, D. (2009). Constrained choice and ethical dilemmas in land management: environmental quality and food safety in california agriculture. J. Agric. Environ. Ethics 22, 53-71. doi: 10.1007/s10806-008-9129-2 
Tendall, D. M., Joerin, J., Kopainsky, B., Edwards, P., Shreck, A., Le, Q. B., et al. (2015). Food system resilience: defining the concept. Glob. Food Sec. 6, 17-23. doi: 10.1016/j.gfs.2015.08.001

The High Level Panel of Experts (HLPE) on Food Security and Nutrition (2019). Agroecological and Other Innovative Approaches for Sustainable Agriculture and Food Systems That Enhance Food Security and Nutrition. Rome: Food and agriculture organization of the united states.

Tobin, D., Jones, K., and Thiede, B. C. (2019). Does crop diversity at the village level influence child nutrition security? Evidence from 11 subSaharan African countries. Popul. Environ. 41, 74-97. doi: 10.1007/s11111-01900327-4

Urruty, N., Tailliez-Lefebvre, D., and Huyghe, C. (2016). Stability, robustness, vulnerability and resilience of agricultural systems. A review. Agron. Sustain. Dev. 36:15. doi: 10.1007/s13593-015-0347-5

van der Werf, H. M., and Petit, J. (2002). Evaluation of the environmental impact of agriculture at the farm level: a comparison and analysis of 12 indicator-based methods. Agric. Ecosyst. Environ. 93, 131-145. doi: $10.1016 /$ S0167-8809(01)00354-1

Vandermeer, J. (1989). The Ecology of Intercropping. Cambridge: Cambridge University Press. doi: 10.1017/CBO9780511623523

Vanek, S. J., and Drinkwater, L. E. (2013). Environmental, social, and management drivers of soil nutrient mass balances in an extensive andean cropping system. Ecosystems 16, 1517-1535. doi: 10.1007/s10021-013-9699-3

Vanek, S. J., Jones, A. D., and Drinkwater, L. E. (2016). Coupling of soil regeneration, food security, and nutrition outcomes in andean subsistence agroecosystems. Food Secur. 8, 727-742. doi: 10.1007/s12571-016-0598-2

Walker, B., Holling, C. S., Carpenter, S. R., and Kinzig, A. (2004). Resilience, adaptability and transformability in social- ecological systems. Ecol. Soc. 9:5. doi: 10.5751/ES-00650-090205

Wander, M. M., Traina, S. J., Stinner, B. R., and Peters, S. E. (1994). Organic and conventional management effects on biologically active soil organic matter pools. Soil Sci. Soc. Am. J. 58, 1130-1139. doi: 10.2136/sssaj1994.03615995005800040018x
Watson, C. A., Öborn, I., Edwards, A. C., Dahlin, A. S., Eriksson, J., Lindström, B. E. M., et al. (2012). Using soil and plant properties and farm management practices to improve the micronutrient composition of food and feed. J. Geochemical Explor. 121, 15-24. doi: 10.1016/j.gexplo.2012.06.015

White, P. J., and Broadley, M. R. (2009). Biofortification of crops with seven mineral elements often lacking in human diets - iron, zinc, copper, calcium, magnesium, selenium and iodine. New Phytol. 182, 49-84. doi: 10.1111/j.1469-8137.2008.02738.x

Wood, S. A. (2018). Nutritional functional trait diversity of crops in south-eastern Senegal. J. Appl. Ecol. 81-91. doi: 10.1111/1365-2664.13026

Wood, S. A., Karp, D. S., DeClerck, F., Kremen, C., Naeem, S., and Palm, C. A. (2015). Functional traits in agriculture: agrobiodiversity and ecosystem services. Trends Ecol. Evol. 30, 531-539. doi: 10.1016/j.tree.2015.06.013

Xue, Y., Xia, H., Christie, P., Zhang, Z., Li, L., and Tang, C. (2016). Crop acquisition of phosphorus, iron and zinc from soil in cereal/legume intercropping systems: a critical review. Ann. Bot. 117, 363-377. doi: 10.1093/aob/mcv182

Zhang, F., and Li, L. (2003). Using competitive and facilitative interactions in intercropping systems enhances crop productivity and nutrient-use efficiency. Plant Soil 248, 305-312. doi: 10.1023/A:1022352229863

Zhang, W., Ricketts, T. H., Kremen, C., Carney, K., and Swinton, S. M. (2007). Ecosystem services and dis-services to agriculture. Ecol. Econ. 64, 253-260. doi: 10.1016/j.ecolecon.2007.02.024

Conflict of Interest: The authors declare that the research was conducted in the absence of any commercial or financial relationships that could be construed as a potential conflict of interest.

Copyright $(0) 2020$ Stratton, Kuhl and Blesh. This is an open-access article distributed under the terms of the Creative Commons Attribution License (CC BY). The use, distribution or reproduction in other forums is permitted, provided the original author(s) and the copyright owner(s) are credited and that the original publication in this journal is cited, in accordance with accepted academic practice. No use, distribution or reproduction is permitted which does not comply with these terms. 